Article

\title{
Hydrothermal Synthesized and Alkaline Activated Carbons Prepared from Glucose and Fructose-Detailed Characterization and Testing in Heavy Metals and Methylene Blue Removal
}

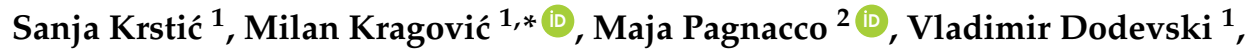 \\ Branka Kaluđerović ${ }^{1}$, Miloš Momčilović ${ }^{1}$, Ivica Ristović ${ }^{3}$ and Marija Stojmenović ${ }^{1}$ \\ 1 Vinča Institute of Nuclear Sciences, University of Belgrade, Mike Petrovića-Alasa 12-14, P.O. Box 522, \\ 11000 Belgrade, Serbia; ssanjak@vin.bg.ac.rs (S.K.); vladimir@vin.bg.ac.rs (V.D.); branka@vin.bg.ac.rs (B.K.); \\ milos@vin.bg.ac.rs (M.M.); mpusevac@vinca.rs (M.S.) \\ 2 Faculty of Physical Chemistry, University of Belgrade, Studentski trg 12-16, 11000 Belgrade, Serbia; \\ maja.milenkovic@ffh.bg.ac.rs \\ 3 Faculty of Mining and Geology, University of Belgrade, 11000 Belgrade, Serbia; ivica.ristovic@rgf.bg.ac.rs \\ * Correspondence: m.kragovic@vin.bg.ac.rs; Tel.: +381-11-6447335
}

Received: 21 May 2018; Accepted: 8 June 2018; Published: 9 June 2018

\begin{abstract}
In the presented paper, activated carbons were prepared from fructose and glucose, and activating agents $(\mathrm{KOH}, \mathrm{NaOH}, \mathrm{LiOH})$ by hydrothermal treatment (HTC) treatment. After preparation, samples were characterized in details. Different techniques were used: x-ray powder diffraction analysis, Raman spectral analysis, elemental analysis, and determination of textural and morphological properties. Obtained results showed dependence of investigated properties and the nature of precursors (glucose or fructose) as well as the type of hydroxides used as activating agents. After characterization, samples were tested as materials for heavy metals $\left(\mathrm{Pb}^{2+}, \mathrm{Cd}^{2+}\right.$ and $\left.\mathrm{Zn}^{2+}\right)$ and methylene blue removal. Also, adsorption experiments were performed on wastewaters taken from tailings of the lead and zinc mine and kinetic of the methylene blue removal was studied. The factors which distinguished the $\mathrm{KOH}$ activated samples were high yield $(\sim 14 \%)$, content of organic carbon $(63-74 \%)$, porosity and specific surface area $\left(S_{\text {BET }} \sim 700-1360 \mathrm{~m}^{2} / \mathrm{g}\right)$, a low degree of the crystal phase, indications that potassium ions may be included in heavy metals removal, good removal of the heavy metal ions $\left(\sim 47-59 \mathrm{mg} / \mathrm{g}\right.$ for $\mathrm{Pb}^{2+}, \sim 21-27 \mathrm{mg} / \mathrm{g}$ for $\mathrm{Cd}^{2+}$ and $\sim 6-10 \mathrm{mg} / \mathrm{g}$ for $\left.\mathrm{Zn}^{2+}\right)$ and fast ( 10-30 $\left.\mathrm{min}\right)$ and good methylene blue $(\sim 60-200 \mathrm{mg} / \mathrm{g})$ removal.
\end{abstract}

Keywords: glucose; fructose; activated carbon; hydrothermal treatment; hydroxide activation; heavy metals; methylene blue

\section{Introduction}

The increasing human need for new products and technologies has led to intensive development of industry. On the other side, industrial development is usually followed by high levels of potentially hazardous materials which may have negative influence on the environment as well as human or animal health. In countries with a good economy, strict rules and laws have caused high control of the level of waste materials being released into the environment, and consequently, due to applying adequate techniques for waste purification, the influence of industry on the environment is usually very small or negligible. On the other hand, in developing countries, control and human consciousness are significantly weaker, which often leads to higher quantities of waste materials being released into the environment and a significant increase of ecological problems as a consequence. 
Heavy metals are one of the most dangerous pollutants in the nature. They are especially toxic for living organisms because of their stability and tendency of accumulation in the environment [1]. With the rapid development of industries such as plating facilities, fertilizers, tanneries, batteries, paper and pesticides, heavy metals wastewaters are increasingly discharged into the environment, either directly or indirectly. Heavy metals are not biodegradable and many of their ions are known to be toxic and carcinogenic. Toxic heavy metals which are of particular concern in the treatment of industrial wastewaters are $\mathrm{Zn}, \mathrm{Cu}, \mathrm{Ni}, \mathrm{Hg}, \mathrm{Cd}, \mathrm{Pb}$ and $\mathrm{Cr}$ [2]. Regarding acute toxicity, cadmium and lead along with mercury form "the big three" of heavy metals with the greatest potential hazard to humans and the environment [3].

Mining presents a significant contribution to economic development in every country, but at the same time it is very often one of the biggest environmental pollutants. Contamination of the environment with heavy metals mainly occurs due to mining activities, i.e., after technological processes of mineral resources where as a result of processing flotation tailings remain [4].

The Grot mine is one of the biggest mines in Serbia, with possibly the most significant influence on the environment. It belongs to the Besna Kobila metallographic region $(1823 \mathrm{~m})$ and it is located in the southeast of Serbia, near the town Vranje (Figure 1). In the Grot mine, the exploitation and processing (flotation) of lead-zinc ore is carried out. Production of ore in the Grot mine is about 14,000 tons of ore monthly, and about 800 tons of lead and zinc concentrate are obtained per month in the flotation of the mine. Tailings of the mine Grot is about 24 ha in area, while the volume of the landfill material in the tailings is about 6 million tons.

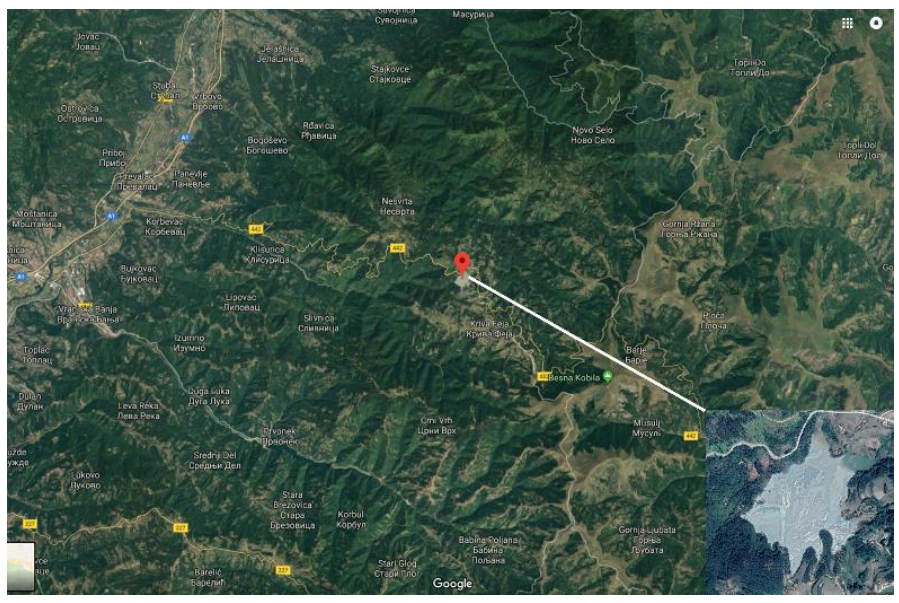

Figure 1. The geographic position of the mine Grot.

The flotation tailings of the mine Grot, Serbia contain $\mathrm{Cd}, \mathrm{Pb}, \mathrm{As}, \mathrm{Cr}, \mathrm{Ni}, \mathrm{Cu}$, etc. The concentrations of mentioned heavy metals are mostly higher than maximum permissible concentrations (MPC) according to the laws of the Republic of Serbia [5]. For that reason, the tailings represent a serious problem for nature and the environment, primarily because of the contamination they generate either by scattering particles from the tailings or by contamination of the soil. However, the most important negative effect, especially for human health, is the release of the wastewater. Namely, contaminated wastewater from tailings, is released without any control and with a flow of about $100 \mathrm{~m}^{3} / \mathrm{h}$, contaminating the river Korbevečka and polluting the South Morava, which belongs to the Danube basin. It is very important to note that rivers which are contaminated with tailings wastewater, especially in the surroundings areas of the tailings, where concentration of the heavy metals are the highest, are very often used by local populations to irrigate gardens and fields as well as to meet other water needs. Thus, it is important to apply necessary actions and procedures for purification and treatment which would prevent or at least minimize the pouring of the wastewater from tailings in the rivers and reduce negative effects on the environment. 
Besides heavy metals, the contamination of waters with organic pollutants, such as dyes is very frequent, and also represents a serious environmental problem. Dyes are widely used in coloring processes in the leather, textile, paper, plastic and wood industries, as well as in food industries [6-8]. Methylene blue (MB) basic cationic dye is the most frequently used dye for leather, cotton, silk and wood [9-11]. It is very dangerous for the respiratory system if inhaled, causing mental confusion and mild poisoning if ingested by mouth $[9,12-14]$. Additionally, MB has been widely used in scientific investigations due to its high level of adsorption on solids, and as a model compound for adsorption characterizations of organic compounds in aqueous solutions [15-17].

It is in common for all mentioned pollutants that they must not be found in nature without control, and for that reason, development of the new materials and techniques which may be used for contaminated waters treatment, either before or after discharging them into nature, represents one of the greatest scientific challenges today.

Different treatment methodologies may be used for that purpose such as adsorption, precipitation, ion-exchange, coagulation, membrane filtration and photo-degradation [18,19]. Among these, adsorption and ion exchange techniques are upgraded methods in terms of their simplicity, recyclability and mode of waste recovery from the pollutants $[18,20]$.

In recent years, a lot of studies have been performed with aim of the selection and/or production of low-cost adsorbents with good adsorption capacities for both organic and inorganic pollutants such as methylene blue or heavy metals. For example, natural materials of both an organic and inorganic nature, such as alginate, chitosan, zeolites, clays, biomaterials, etc. are classified as adsorbents with potential to be widely used for the treatment of waters contaminated with heavy metals. They are available in large quantities and are low-cost, often biodegradable, usually recyclable and show high adsorption ability towards a great number of heavy metal ions [21-24]. On the other side, Bukallah et al. (2008) [25] described the removal of methylene blue from an aqueous solution by adsorption on sand, while Tang et al. (2017) [26] showed good adsorption properties for MB of the agricultural residue walnut shell. Tahir et al. (2008) followed adsorption of the methylene blue by using bioabsorbents such as Ulva lactuca and Sargassum [27].

Besides mentioned adsorbents, activated carbons (ACs) are very beneficial materials for different uses such as power transfer, production wearable sensing and sensor application nanofibers [28-35]. In addition, their use is particularly significant in inorganic or organic pollutants removal, due to a large number of unique characteristics, such as a highly developed porous structure, large surface area, variability in surface chemistry, and a high level of surface activity [33-35]. The major drawback of the conventional activated carbon-based adsorption process is the usage of non-renewable and relatively expensive raw materials (i.e., wood and coal), and therefore, it is still considered to be a high cost process with restricted applicability. To overcome such drawbacks and attain better economic viability, adsorption processes using non-conventional low-cost activated carbons derived from renewable and inexpensive materials such as naturally abundant biomass, saccharides, agricultural and industrial wastes have been examined by different researchers [36-39].

In general, for potential practical application of the material for pollutants removal from aqueous solutions, it is very important that the material should possess any kind of universality, i.e., possess the ability to remove different contaminants. For activated carbons, universality and adsorption properties, structure, carbon content, specific surface, etc. are very important [40] and to get material with the best properties, it is necessary to apply different preparing conditions and perform detailed characterization as well.

In the presented paper, activated carbons were prepared by hydrothermal synthesis from easily accessible, eco-friendly and low-cost materials (glucose and fructose) and activated with different hydroxides in order to get the best properties for use in removal different (inorganic and organic) pollutants from contaminated aqueous solutions. The obtained samples were characterized in detail and then checked for removal of the inorganic (heavy metals) and organic (methylene blue) pollutants 
from contaminated aqueous solutions. Experiments were also performed on real wastewater samples taken from tailings of the lead and zinc mine, but experiments were performed in laboratory conditions.

\section{Materials and Methods}

Chemicals that were used in this study were of high purity and supplied from Sigma Aldrich, Darmstadt, Germany.

\subsection{Synthesis of the Samples}

Synthesis of activated carbon materials was performed in two steps. At first, required amounts of glucose $(\mathrm{G})$ and fructose $(\mathrm{F})$ were dissolved in deionized water in order to prepare solutions with a concentration of $1.0 \mathrm{~mol} / \mathrm{dm}^{3}$. Hydrothermal synthesis was carried out in the PTFE (polytetrafluoroethylene) chamber placed in a stainless steel autoclave. Prepared solutions were placed into autoclave and heated into an oven under autogenous pressure at $240{ }^{\circ} \mathrm{C}$ for $24 \mathrm{~h}$. Afterward, samples were filtrated, washed with distilled water and dried for $1 \mathrm{~h}$ at $100^{\circ} \mathrm{C}$.

The second part of experiments was activation of carbon containing materials with selected hydroxides $(\mathrm{KOH}, \mathrm{NaOH}$ and $\mathrm{LiOH})$ as activation agents. Chemical activation was performed by dry mixing of selected precursor and hydroxide at room temperature with the ratio 1:3. Subsequently, the mixed samples were activated in a horizontal tube furnace (Protherm Furnaces, model PTF $16 / 38 / 250$, Ankara, Turkey) at $750{ }^{\circ} \mathrm{C}, 200 \mathrm{~cm}^{3} / \mathrm{min}$ nitrogen flow and the heating rate of $5{ }^{\circ} \mathrm{C} / \mathrm{min}$, with a retention time of $1 \mathrm{~h}$.

Activated carbons obtained by this procedure were designated as AC@G-T- $\mathrm{N}_{2}-\mathrm{t}-\mathrm{XOH}$ and $\mathrm{AC} @ \mathrm{~F}-\mathrm{T}-\mathrm{N}_{2}-\mathrm{t}-\mathrm{XOH}$, where $\mathrm{G}$ and $\mathrm{F}$ are precursors, $\mathrm{N}_{2}$ is activation gas, $\mathrm{T}$ and $\mathrm{t}$ are temperature and time of activation while $\mathrm{XOH}$ represent activation agents $(\mathrm{X}=\mathrm{Li}, \mathrm{Na}, \mathrm{K})$. During activations the following yields were obtained: 6.0; 7.9 and 13.6 for $\mathrm{LiOH}, \mathrm{NaOH}$ and $\mathrm{KOH}$ activated glucose, respectively, and 6.4; 7.4 and 13.5 for $\mathrm{LiOH}, \mathrm{NaOH}$ and $\mathrm{KOH}$ activated fructose, respectively.

\subsection{Characterization Methods}

The crystal structure of the obtained samples was characterized by x-ray powder diffraction (XRPD) analysis using Ultima IV Rigaku diffractometer (Rigaku, The Woodlands, TX, USA), equipped with $\mathrm{Cu} \mathrm{K} \alpha 1,2$ radiation source (a generator voltage of $40.0 \mathrm{kV}$ and a generator current of $40.0 \mathrm{~mA}$ ). All samples were recorded in the range of $10-90^{\circ} 2 \theta$, with a scanning step of $0.02^{\circ}$ and at a scan rate of $2^{\circ} / \mathrm{min}$.

Raman spectra of activated carbons were collected on a DXR Raman microscope (Thermo Scientific, Waltham USA) equipped with an Olympus optical microscope and a CCD detector, with a diode pumped solid state high-brightness laser $(532 \mathrm{~nm})$ and a $10 \times$ objective. The powdered sample was placed on $\mathrm{X}-\mathrm{Y}$ motorized sample stage. The analysis of the scattered light was carried out by the spectrograph with a grating 900 lines $/ \mathrm{mm}$. The laser power was $1 \mathrm{~mW}$.

Elemental analyses of samples were performed on a Vario EL III C, H, N, S/O Elemental Analyzer (Elementar, Langenselbold, Germany). The amounts of $\mathrm{C}, \mathrm{N}$ and $\mathrm{H}$ were determined directly while the amount of oxygen was calculated as: $100 \%-\mathrm{ash} \%-\mathrm{C} \%-\mathrm{N} \%-\mathrm{H} \%$.

The adsorption/desorption isotherms of activated carbons based on adsorption/desorption of $\mathrm{N}_{2}$ at $77 \mathrm{~K}$ were determined using a Micromeritics, model TriStar II 3020 (Micromeritics, Norcross, GA, USA). Degassing of samples under a $\mathrm{N}_{2}$ stream (purity 6.0) and programmed bi-level heating (the first heating stage was at $90{ }^{\circ} \mathrm{C}$ during $60 \mathrm{~min}$; the second heating stage was at $250{ }^{\circ} \mathrm{C}$ during $\left.240 \mathrm{~min}\right)$. The specific surface area $\left(\mathrm{S}_{\mathrm{BET}}\right)$ of obtained samples was calculated by the law of BET (Brunauer, Emmet, Teller) theory [41] from the best linear fit in the region $p / p_{\mathrm{o}}<0.01$ ( $p$ and $p_{\mathrm{o}}$ represent the equilibrium and saturation pressures of nitrogen at a fixed temperature). Using BJH (Barrett, Joyner and Halenda) method [41], for every sample from desorption branch of the nitrogen isotherm pore-size distributions were calculated. In addition, mesopore surface $\left(\mathrm{S}_{\text {meso }}\right)$ and micropore volume $\left(\mathrm{V}_{\text {micro }}\right)$ were also calculated from the isotherms. By using the 
high-resolution $\alpha_{\mathrm{s}}$-plot method [42-45], mesopore surface area $\left(\mathrm{S}_{\text {meso }}\right)$ and micropore volume $\left(\mathrm{V}_{\text {micro }}\right)$ were determined. Micropore surface $\left(S_{\text {micro }}\right)$ was calculated by subtracting $S_{\text {meso }}$ from the $S_{\text {BET }}$.

The morphology of the investigated activated carbons was examined by scanning electron microscope Tescan MIRA3 XM FESEM (Tescan, Brno-Kohoutovice, Czech Republic).

\subsection{Adsorption Experiments}

Experiments on testing availability of the selected samples to be used in area of environmental protection and purification of waters contaminated with heavy metals were performed under batch conditions for the single component solutions of lead(II)-nitrate, cadmium(II)-nitrate and zinc(II)-nitrate of known heavy metal ions concentrations ( $\left.700 \mathrm{mg} / \mathrm{dm}^{3}\right)$. For that purpose, $0.5 \mathrm{~g}$ of the adsorbents were mixed with $50 \mathrm{~cm}^{3}$ of heavy metals solutions at $350 \mathrm{rpm}, 24 \mathrm{~h}$ at initial $\mathrm{pH}$ 4.2 and room temperature. Initial $\mathrm{pH}$ was adjusted by adding very small quantities (few drops) of $0.1 \mathrm{~mol} / \mathrm{dm}^{3} \mathrm{HNO}_{3}$. After reaction time the suspensions were centrifuged, and concentrations of the heavy metals, as well as concentrations of potassium, sodium and lithium ions, were determined from the supernatants using an atomic absorption spectrometer (AAS) Analytic Jena 300 (Analytic Jena, Jena, Germany). Final pH was also measured. In the second step, adsorption experiments were performed on wastewater taken from tailings of the lead and zinc flotation facility Grot, Vranje, Serbia. The samples were taken from the outlet pipe of the flotation facility (OF) and hydro-cyclone overflow (PHC) in accordance with standard procedure [46]. Collected samples were kept in the capped container and left at room temperature in order to separate liquid from the solid phase. After few days, the liquid phase was decanted and filtered through qualitative filter paper in order to remove large particles and impurities. The adsorption experiments were performed under the following batch conditions: $0.5 \mathrm{~g}$ of the adsorbent was mixed with $50 \mathrm{~cm}^{3}$ of the contaminated water for $24 \mathrm{~h}$. According to SRPS ISO 5667-10:2007, during sampling, the wastewater is mixed with a solution of nitric acid in order to stabilize it, so the $\mathrm{pH}$ of the solution after sampling and before materials testing was $\sim 4.2$. For that reason, all experiments related to heavy metals removal were performed at initial $\mathrm{pH}=4.2$ and final $\mathrm{pHs}$ were measured. After $24 \mathrm{~h}$ the suspensions were centrifuged, and the initial and non-adsorbed concentrations of heavy metals were determined using an inductively coupled plasma optical emission spectrometry (ICP-OES) on an ICP spectrometer Spectroflame (Spectro Analytical Instruments, Kleve, Germany).

The adsorption experiments for dyes were carried out in magnetically stirred $(\sigma=400 \mathrm{rpm})$ glass vessel. Testing of the methylene blue (MB) adsorption was performed for initial MB concentration of $200 \mathrm{mg} / \mathrm{dm}^{3}$ in distilled water at room temperature and under conditions protected from light. In order to simulate real conditions, the initial $\mathrm{pH}(6.6)$ as well as final $\mathrm{pH}$ were not adjusted and were only measured. The solid/liquid ratio applied in these experiments was $25 \mathrm{mg} / 25 \mathrm{~cm}^{3}$. The contact time was $24 \mathrm{~h}$. The kinetic experiments were performed with the concentration of the $\mathrm{MB}$ of $50 \mathrm{mg} / \mathrm{dm}^{3}$, and other conditions as in previous experiments $(250 \mathrm{mg}$ of the adsorbents were mixed with a 250 $\mathrm{cm}^{3} \mathrm{MB}$ solution). At a specific time, $1 \mathrm{~cm}^{3}$ of the solutions were taken, centrifuged and analyzed on Agilent 8435 UV-VIS spectrophotometer with a diode array detector (Agilent, Santa Clara, CA, USA). The two maximum wavelengths for MB were used, the first in the ultraviolet (UV) and the second one in the visible (VIS) range of electromagnetic spectrum. Thus, the absorption spectra were collected at $291 \mathrm{~nm}$ and $664 \mathrm{~nm}$.

\section{Results}

\subsection{Characterization}

\subsubsection{XRPD Analysis and Raman Spectroscopy}

It is known that when a substance is dissolved in water or some other solvent, its crystal structure is destroyed. That means that in the first stage of obtaining samples for this study, during the 
preparation of a $1 \mathrm{~mol} / \mathrm{dm}^{3}$ solution of glucose or fructose, their crystalline structures were destroyed. Then, it is also known from the literature $[47,48]$ that because of HTC treatment, an amorphous network with a high content of carbon is obtained with increased surface functional properties so it may be said that HTC-obtained carbon containing materials from glucose and fructose do not possess crystal structures. It was of interest to determine whether additional activation with different hydroxides had an influence on crystalline structures of prepared carbonaceous materials, i.e., whether activation takes place in the same way on both sugars. For that reason, XRPD analyses of samples AC@G-T- $\mathrm{N}_{2}-\mathrm{t}-\mathrm{XOH}$ and $\mathrm{AC} @ \mathrm{~F}-\mathrm{T}-\mathrm{N}_{2}-\mathrm{t}-\mathrm{XOH}$ were performed and the results are shown in Figure 2.
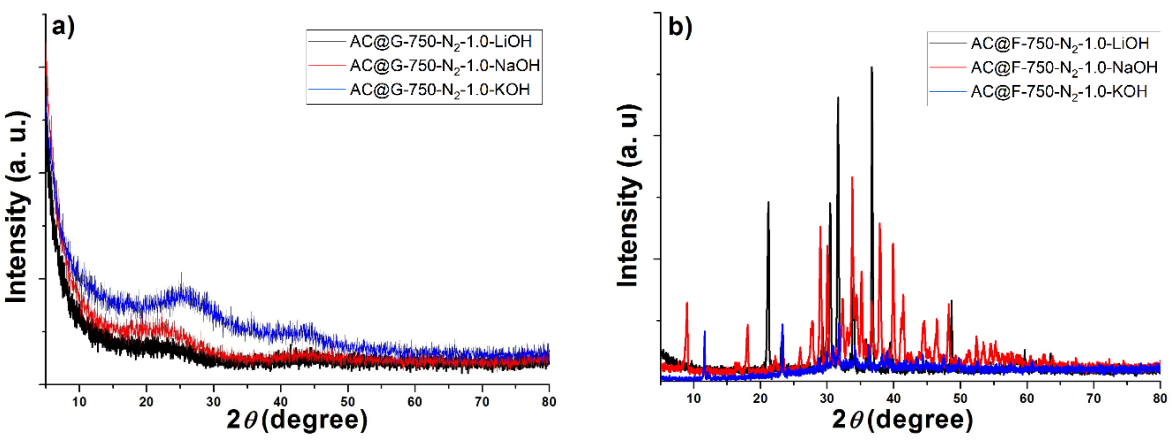

Figure 2. The XRPD patterns of activated carbons: (a) AC@G-T- $\mathrm{N}_{2}-\mathrm{t}-\mathrm{XOH}$ and (b) AC@F-T- $\mathrm{N}_{2}-\mathrm{t}-\mathrm{XOH}$.

The results presented in Figure 2a are for samples obtained from glucose, which showed that there are no significant differences in the shape of XRPD curves for samples activated with different hydroxides, and broad peaks between $2 \theta$ value $\sim 26^{\circ}$ and $\sim 44^{\circ}$ are visible. That is characteristic for materials with an amorphous structure and is ascribed to typical graphitic (002) and (100) planes. The broadening of the two peaks suggests the low graphitization degree and the presence of amorphous carbon in all three AC@G-T-N $2-t-X O H$ samples [49].

The XRPD diagrams presented in Figure 2b for AC@F-T- $\mathrm{N}_{2}-\mathrm{t}-\mathrm{XOH}$ showed sharp and well-defined peaks, which indicate that besides amorphous, presence of a defined (crystal) structural arrangement occurs in all three fructose samples. According to the database in international center for diffraction data (ICDD), the peak positions indicate the presence of carbonates $\left(X_{2} \mathrm{CO}_{3}\right)(\mathrm{ICDD}$ 01-074-6256) as well as oxides $\left(\mathrm{X}_{2} \mathrm{O}\right.$ ) (ICDD 01-072-1216) [50] ( $\mathrm{X}$ is $\mathrm{Li}, \mathrm{Na}$ or $\mathrm{K}$ ) in form of crystal phases in all samples obtained from fructose. The most pronounced peaks (the highest content of crystal phases, oxides and carbonates) are observed for the sample obtained by activating with $\mathrm{LiOH}$, while the characteristic peaks are the weakest for the sample activated with $\mathrm{KOH}$. That is expected since the reactivity of alkaline metals is changed in the following order: $\mathrm{Li}>\mathrm{Na}>\mathrm{K}$. The different behavior of glucose and fructose sample after activation with three hydroxides, may be explained as a result of different oxidation potential two samples, which is significantly higher for fructose [51], and consequently indicates greater ability of fructose to build oxides and other similar compounds in comparison with glucose.

To confirm differences in crystal structures of the activated samples, Raman spectrometric analyses were performed, and results are presented in Figure 3a and b. In Raman spectra, two typical Raman modes at around 1595 and $1340 \mathrm{~cm}^{-1}$ are clearly visible in all investigated samples.

The Raman mode (G-band) at around $1595 \mathrm{~cm}^{-1}$ corresponds to the graphitic lattice vibration of $\mathrm{sp}_{2}$-bonded carbon atoms [52], while Raman mode (D-band) at around $1340 \mathrm{~cm}^{-1}$ is associated with the presence of defects in the graphite layer [53]. Integrated peak areas $\left(\mathrm{I}_{\mathrm{D}}\right.$ and $\left.\mathrm{I}_{\mathrm{G}}\right)$ were calculated for both peaks and used for determination of the graphitization degrees, which is equal to peaks intensity ratios of $\mathrm{D}-$ and $\mathrm{G}$-bands $\left(\mathrm{I}_{\mathrm{D}} / \mathrm{I}_{\mathrm{G}}\right)$. The $\mathrm{I}_{\mathrm{D}} / \mathrm{I}_{\mathrm{G}}$ value is a measure of the crystallinity of the sample. The increase of its value corresponds to decrease of the crystallinity of the sample and vice versa $[47,54]$. From the literature $[55]$ the $\mathrm{I}_{\mathrm{D}} / \mathrm{I}_{\mathrm{G}}$ value lower than 0.25 indicated perfect crystallinity with a low degree of crystal defects. For samples investigated in this study, the $\mathrm{I}_{\mathrm{D}} / \mathrm{I}_{\mathrm{G}}$ values were 
much higher, meaning that all samples possess lower crystallinities or crystallinities with the presence of defects (amorphous phase) what confirmed results of XRPD analyses.

The $\mathrm{I}_{\mathrm{D}} / \mathrm{I}_{\mathrm{G}}$ values for activated carbons obtained from glucose were higher in comparison with values for samples obtained from fructose (for $\mathrm{KOH}$ activated samples: 2.14 (glucose) and 1.65 (fructose); for $\mathrm{NaOH}$ activated samples: 2.06 (glucose) and 1.51 (fructose); and for $\mathrm{LiOH}$ activated samples: 1.72 (glucose) and 1.41 (fructose)) confirming the presence of a higher degree of amorphousity in samples obtained from glucose.
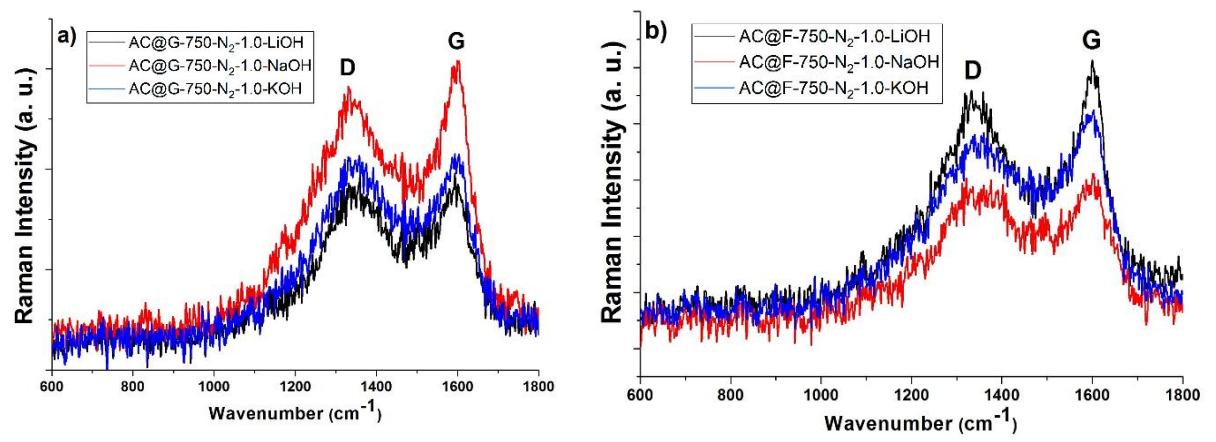

Figure 3. The Raman spectra of activated carbons: (a) AC@G-T- $\mathrm{N}_{2}-\mathrm{t}-\mathrm{XOH}$ and (b) AC@F-T- $\mathrm{N}_{2}-\mathrm{t}-\mathrm{XOH}$.

\subsubsection{Elemental Analysis}

The contents of organic C, N, O and H in glucose and fructose samples obtained after hydrothermal treatment and activation with different hydroxides were determined by elemental analysis and the results are listed in Table 1.

Table 1. Elemental analysis of the glucose and fructose activated carbons.

\begin{tabular}{cccccc}
\hline Sample & N & C & H & Ash & O \\
\hline AC@G-750- $\mathrm{N}_{2}-1.0-\mathrm{LiOH}$ & 0.95 & 61.94 & 3.88 & 33.24 & 10.21 \\
AC@G-750-N $2-1.0-\mathrm{NaOH}$ & 0.04 & 72.89 & 1.49 & 25.58 & 9.08 \\
AC@G-750-- N $2-1.0-\mathrm{KOH}$ & 0.36 & 74.06 & 1.79 & 23.79 & 19.62 \\
AC@F-750-N $2-1.0-\mathrm{LiOH}$ & 0.08 & 38.05 & 1.42 & 60.45 & 22.33 \\
AC@F-750-- ${ }_{2}-1.0-\mathrm{NaOH}$ & 0.68 & 70.71 & 2.74 & 25.88 & 8.66 \\
AC@F-750- $\mathrm{N}_{2}-1.0-\mathrm{KOH}$ & 0.51 & 62.99 & 3.45 & 33.05 & 10.17 \\
\hline
\end{tabular}

Presented results showed that the content of organic carbon in samples obtained from glucose was higher in comparison with those obtained from fructose after activation with the same hydroxide. For example, after activation with $\mathrm{LiOH}$, the content of carbon was $\sim 62 \%$ for AC@G-750- $\mathrm{N}_{2}-1.0-\mathrm{LiOH}$ and $\sim 38 \%$ for AC@F-750- $\mathrm{N}_{2}-1.0-\mathrm{LiOH}$. Also, for both sample types (glucose and fructose), the content of organic carbon was much higher after activation with $\mathrm{NaOH}$ and $\mathrm{KOH}$ in comparison with samples obtained by activation with $\mathrm{LiOH}$. That may be explained as a consequence of the formation of crystal layers after activation which are reach with carbonates and oxides, whereby this phenomenon is the most pronounced for fructose and $\mathrm{LiOH}$ activated samples, while the least pronouncing was obtained for $\mathrm{KOH}$ activated samples. That is also confirmed by XRPD and Raman spectrometry and is described in Section 3.1.1. Variation in oxygen and hydrogen contents may be explained with formation of the oxides and releasing of the water molecules during activation reactions or due to carbonization as well as decomposition of oxygen-containing functional groups at a high temperature [56-58], while presence of insignificant amounts of nitrogen can be a consequence of lagging of nitrogen which was used as an inert atmosphere for obtaining investigated samples.

\subsubsection{Textural Properties}

Textural properties are one of the most important parameters for practical application of the materials, at first in the field of environmental protection in adsorption and removal of different 
pollutants, inorganic or organic. From that reason carbon samples prepared from glucose and fructose and activated by different hydroxides $(\mathrm{LiOH}, \mathrm{NaOH}$ and $\mathrm{KOH})$ were characterized by adsorption/desorption of $\mathrm{N}_{2}$ at $77 \mathrm{~K}$ and results are presented in Figure 4a for glucose and Figure $4 \mathrm{~b}$ for fructose. Also, for a better comparison, the influence of different activation agents on structure, porosity developments and pore-size distributions were determined and presented as inserts in Figure 4 (insets 1, 2 and 3). As it is clear from Figure $4 a$ and b, for all samples similar isotherms of type I according to IUPAC classification [46] were obtained, which means that all investigated samples pose dominant microporous structure. The calculated values of specific surface areas $\left(\mathrm{S}_{\mathrm{BET}}\right)$, mesopore surfaces $\left(\mathrm{S}_{\text {meso }}\right)$, micropore surfaces $\left(\mathrm{S}_{\text {mic }}\right)$, micropores volume $\left(\mathrm{V}_{\text {mic }}\right)$ and average pore diameters $\left(\mathrm{d}_{\text {pore }}\right)$ are shown in Table 2 . To compare results, the same parameters for HTC-G and HTC-F are also presented in Table 2 where is visible the lack of porosity in chars produced by HTC.
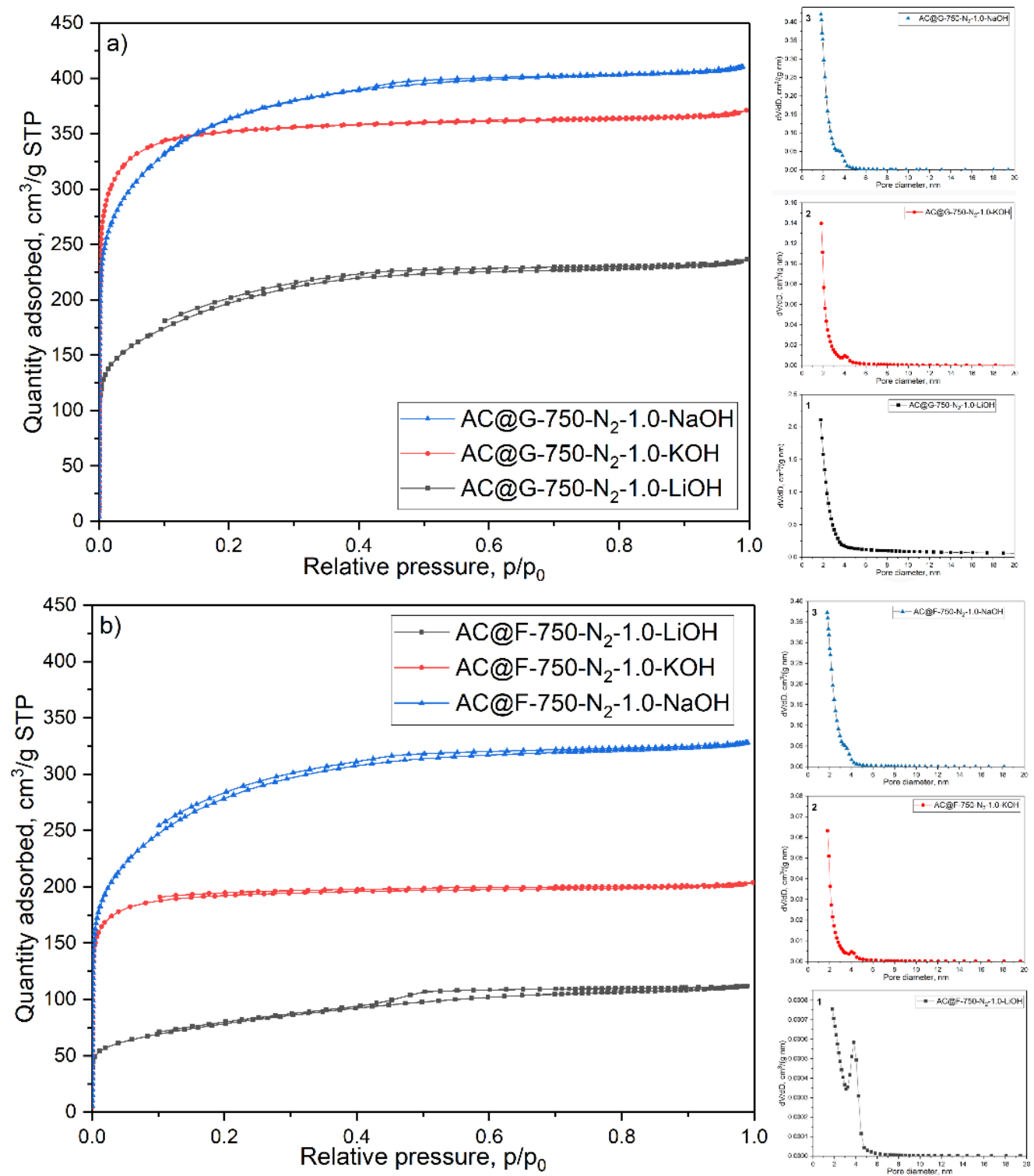

Figure 4. $\mathrm{N}_{2}$ adsorption-desorption isotherms of (a) glucose and (b) fructose. Insets: influence of different activation agents $(\mathrm{KOH}, \mathrm{NaOH}$ and $\mathrm{LiOH})$ on structure, porosity developments and pore-size distributions. 
Table 2. Textural properties of investigated samples: specific surface areas $\left(\mathrm{S}_{\mathrm{BET}}\right)$, mesopore surface $\left(\mathrm{S}_{\text {meso }}\right)$, micropore surface $\left(\mathrm{S}_{\mathrm{mic}}\right)$, micropore volume $\left(\mathrm{V}_{\mathrm{mic}}\right)$ and average pore diameter $\left(\mathrm{d}_{\text {pore }}\right)$.

\begin{tabular}{|c|c|c|c|c|c|}
\hline Samples & $\mathrm{S}_{\text {BET }}\left(\mathrm{m}^{2} / \mathrm{g}\right)$ & $S_{\text {meso }}\left(\mathrm{m}^{2} / \mathrm{g}\right)$ & $S_{\text {mic }}\left(\mathrm{m}^{2} / \mathrm{g}\right)$ & $V_{\text {mic }}\left(\mathrm{cm}^{3} / \mathrm{g}\right)$ & $d_{\text {pore }}(\mathrm{nm})$ \\
\hline $\begin{array}{l}\text { HTC-G } \\
\text { HTC-F }\end{array}$ & $<10$ & - & - & - & - \\
\hline AC@G-750- $\mathrm{N}_{2}-1.0-\mathrm{LiOH}$ & 688 & 37 & 651 & 0.21 & 2.40 \\
\hline AC@G-750- $\mathrm{N}_{2}-1.0-\mathrm{NaOH}$ & 1291 & 179 & 1112 & 0.24 & 2.60 \\
\hline AC@G-750-N $2-1.0-\mathrm{KOH}$ & 1357 & 195 & 1162 & 0.09 & 2.60 \\
\hline $\mathrm{AC@F}-750-\mathrm{N}_{2}-1.0-\mathrm{LiOH}$ & 272 & 32 & 240 & 0.13 & 2.80 \\
\hline $\mathrm{AC@F}-750-\mathrm{N}_{2}-1.0-\mathrm{NaOH}$ & 953 & 46 & 907 & 0.28 & 2.40 \\
\hline AC@F-750-N $2-1.0-\mathrm{KOH}$ & 701 & 94 & 607 & 0.04 & 2.60 \\
\hline
\end{tabular}

From Table 2 it is clear that activation by $\mathrm{NaOH}, \mathrm{KOH}$ and $\mathrm{LiOH}$ of the glucose and fructose sample previously hydrothermal synthesized (HTC-G and F) has a positive effect on the textural properties, and for all investigated samples specific surface areas increased from $<10 \mathrm{~m}^{2} / \mathrm{g}$ to more than $270 \mathrm{~m}^{2} / \mathrm{g}$ after activation. In all glucose and fructose samples, the smallest increase in the specific surface area is achieved with $\mathrm{LiOH}\left(S_{B E T}=688\right.$ and $272 \mathrm{~m}^{2} / \mathrm{g}$ for glucose and fructose activated sample, respectively). Significant better results were obtained for $\mathrm{NaOH}$ and $\mathrm{KOH}$ activated samples (1291 and $953 \mathrm{~m}^{2} / \mathrm{g}$ for $\mathrm{NaOH}$ and 1357 and $701 \mathrm{~m}^{2} / \mathrm{g}$ for $\mathrm{KOH}$ activated glucose and fructose sample, respectively). Clearly visible crystal phases containing oxides and carbonates that are detected by XRPD analyses in samples obtained from fructose may be an explanation for lower specific surface areas in comparison with glucose samples. This is in agreement with results published by Mopoung et al. [59], where activated carbon was prepared from Tamarind Seeds by activation with $\mathrm{KOH}$. Authors also found that potassium compounds in form of crystal phase produced at the surface of the activated carbon caused lowering of the BET surface area. Also, from Table 2, it may be seen that the $\mathrm{KOH}$ activated sample obtained from fructose possess a lower specific surface area in comparison with samples activated with $\mathrm{NaOH}$ that is opposite from samples obtained from glucose. The reason for that is the lower carbon content in the AC@F-750- $\mathrm{N}_{2}-1.0-\mathrm{KOH}$ than in AC@F-750- $\mathrm{N}_{2}-1.0-\mathrm{NaOH}$ (Table 1). The same ratio between specific surface area and carbon content in activated carbon was also found by other authors [60]. Also, BET surface areas of all samples showed very good agreement with results of the elemental analysis (Table 1 ) and the value of $S_{B E T}$ is changed in the same manner as carbon content in the investigated samples.

\subsubsection{SEM Analysis}

In order to explain and realize differences in morphological properties which occur due to activation by various hydroxides, SEM analyses of samples were performed and results are presented in Figure $5 \mathrm{a}-\mathrm{c}$ for glucose, and Figure $5 \mathrm{~d}-\mathrm{f}$ for fructose samples activated with different hydroxides. Obtained results were also compared with the results of SEM analyses of the samples (results are not shown) after hydrothermal treatment of glucose and fructose, where it was visible that microspheres, which are the typical morphologies of carbohydrate-derived chars, were developed after hydrothermal treatment.

As it may be seen from Figure $5 \mathrm{a}, \mathrm{b}$, after activation of the glucose sample with $\mathrm{LiOH}$ and $\mathrm{NaOH}$ HTC-obtained sample maintained its morphological properties and well defined, interconnected spherical microparticles were obtained with a diameter in the range of $3-4 \mu \mathrm{m}$. For the same hydroxides, for the fructose sample, the same trend was obtained (Figure $5 \mathrm{~d}, \mathrm{e}$ ) and spherical, interconnected microparticles are also visible, but with differences in particle size and sphere diameters were in a range from $\sim 0.5$ to $\sim 1.0 \mu \mathrm{m}$. However, after activation with $\mathrm{KOH}$, for both samples the spherical morphology was destroyed (Figure $5 \mathrm{c}, \mathrm{f})$. The reason for that and for the generation of pore networks may be various redox reactions which take place between carbon and potassium compounds such as gasification reaction and ejection of carbon in form of oxides, then releasing water molecules and $\mathrm{KOH}$ reduction to metal $\mathrm{K}$. At the same time, $\mathrm{K}_{2} \mathrm{CO}_{3}$ which may also be formed during the activation, may be reduced by carbon to $\mathrm{K}, \mathrm{K}_{2} \mathrm{O}, \mathrm{CO}$, and $\mathrm{CO}_{2}$ what also, as a consequence, may have creating porous 
carbon surface. An additional reason for microstructure destroying is that since the boiling point of $\mathrm{K}$ is close to $750{ }^{\circ} \mathrm{C}$ (temperature of activation), it is possible that potassium remains in the activated carbon structure and changes it [60-62]. On the other side, the boiling points of the Li and $\mathrm{Na}$ are much higher than activation temperature, so the possibility of their entering into the structure of the activated carbon and chaining is much lower, what may be a reason for maintaining morphological properties of the carbon containing material.

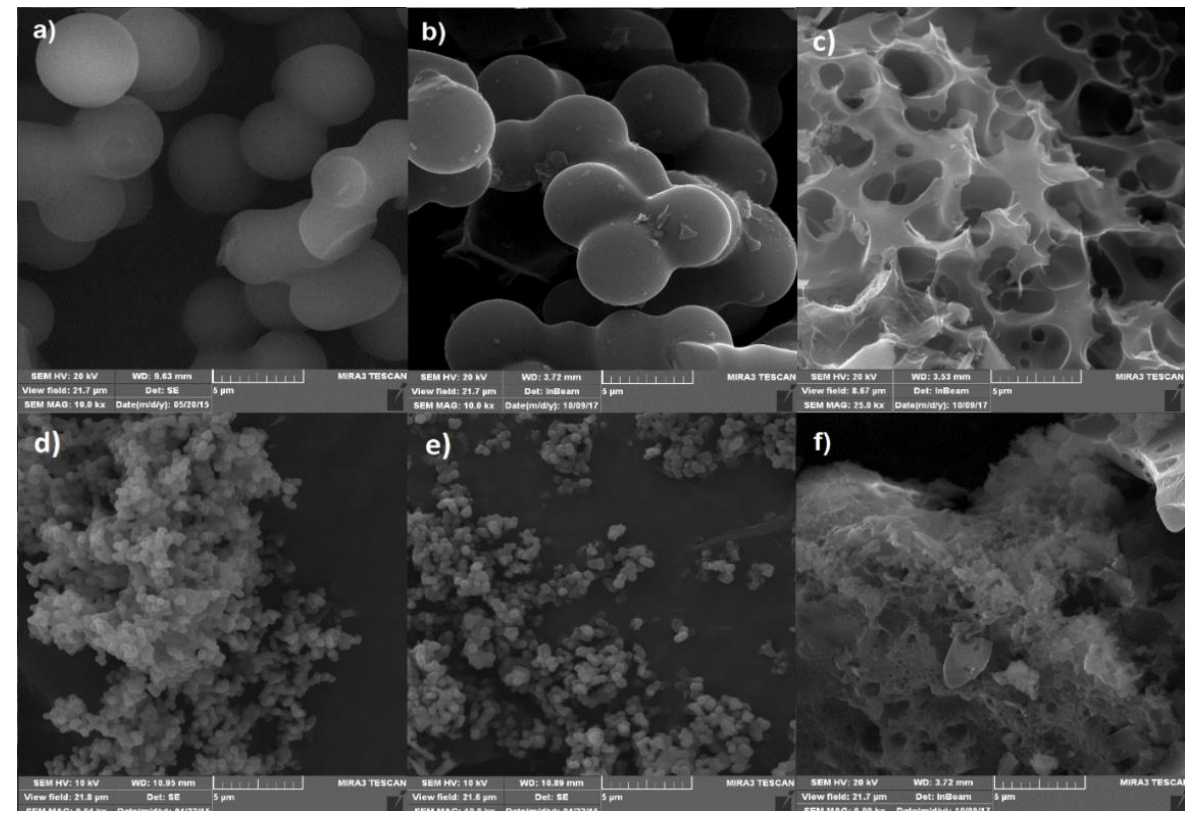

Figure 5. SEM micrographs of activated carbons obtained by using different hydroxides: (a) AC@G-750- $\mathrm{N}_{2}-1.0-\mathrm{LiOH} ;$ (b) AC@G-750- $\mathrm{N}_{2}-1.0-\mathrm{NaOH} ; \quad$ (c) AC@G-750- $\mathrm{N}_{2}-1.0-\mathrm{KOH}$, (d) AC@F-750- $\mathrm{N}_{2}-1.0-\mathrm{LiOH}$; (e) AC@F-750- $\mathrm{N}_{2}-1.0-\mathrm{NaOH}$ and (f) $\mathrm{AC} @ \mathrm{~F}-750-\mathrm{N}_{2}-1.0-\mathrm{KOH}$.

\subsection{Adsorption Experiments}

\subsubsection{Removal of Heavy Metals from Aqueous Solutions}

Results of characterization gave an indication that besides all prepared samples, the one that was obtained by activation with $\mathrm{KOH}$ should be the best candidate for heavy metals removal. The reasons for that are: the best yield, the lowest degree of the crystal phase, the highest porosity, very high specific surface area, as well as the high content of organic carbon. In addition, ion exchange is one of the most common mechanisms involved in heavy metals removal on different adsorbents, and results of characterization gave an indication that potassium ions may be inserted in the structure of the activated carbons and from that point potential available for ion exchange with heavy metal ions from surrounding aqueous solution.

To confirm that, the testing of removal of different (model) heavy metal ions $\left(\mathrm{Pb}^{2+}, \mathrm{Cd}^{2+}\right.$ and $\left.\mathrm{Zn}^{2+}\right)$ from the aqueous solution was performed by all prepared samples for the same initial concentrations of heavy metals and the results are shown in Tables 3 and 4.

From results presented in Table 3 it is clear that under applied experimental conditions, all investigated samples showed the highest affinity for lead cations, followed with cadmium, while for the removal of $\mathrm{Zn}^{2+}$ affinity was the weakest. Also, as expected, the samples activated with $\mathrm{KOH}$ showed better removal of all three heavy metal cations in comparison with those activated with $\mathrm{LiOH}$ and $\mathrm{NaOH}$. 
Table 3. Amounts of heavy metals removed from waters solutions by using samples prepared from glucose and fructose and activated with different hydroxides. $\mathrm{C}_{\mathrm{i}}$-initial concentration; $\mathrm{C}_{\mathrm{a}}$-removed amount.

\begin{tabular}{|c|c|c|c|c|c|c|}
\hline Sample & $\begin{array}{l}\mathrm{C}_{\mathrm{i}}\left(\mathrm{Pb}^{2+}\right), \\
\mathrm{mg} / \mathrm{dm}^{3}\end{array}$ & $\begin{array}{l}\mathrm{C}_{\mathrm{a}}\left(\mathrm{Pb}^{2+}\right) \\
\mathrm{meq} / 100 \mathrm{~g}\end{array}$ & $\begin{array}{c}\mathrm{C}_{\mathrm{i}}\left(\mathrm{Cd}^{2+}\right) \\
\mathrm{mg} / \mathrm{dm}^{3}\end{array}$ & $\begin{array}{l}\mathrm{C}_{\mathrm{a}}\left(\mathrm{Cd}^{2+}\right) \\
\mathrm{meq} / 100 \mathrm{~g}\end{array}$ & $\begin{array}{c}\mathrm{C}_{\mathrm{i}}\left(\mathrm{Zn}^{2+}\right) \\
\mathrm{mg} / \mathrm{dm}^{3}\end{array}$ & $\begin{array}{l}\mathrm{C}_{\mathrm{a}}\left(\mathrm{Zn}^{2+}\right) \\
\mathrm{meq} / 100 \mathrm{~g}\end{array}$ \\
\hline AC@G-750- $\mathrm{N}_{2}-1.0-\mathrm{KOH}$ & \multirow{6}{*}{680} & 45.3 & \multirow{6}{*}{715} & 37.0 & \multirow{6}{*}{645} & 16.8 \\
\hline AC@G-750- $\mathrm{N}_{2}-1.0-\mathrm{NaOH}$ & & 32.4 & & 24.9 & & 14.7 \\
\hline AC@G-750-N $2-1.0-\mathrm{LiOH}$ & & 12.0 & & 11.0 & & 6.16 \\
\hline AC@F-750-N $2-1.0-\mathrm{KOH}$ & & 56.6 & & 48.4 & & 30.6 \\
\hline $\mathrm{AC} @ \mathrm{~F}-750-\mathrm{N}_{2}-1.0-\mathrm{NaOH}$ & & 42.0 & & 40.0 & & 26.0 \\
\hline AC@F-750- $\mathrm{N}_{2}-1.0-\mathrm{LiOH}$ & & 7.8 & & 9.6 & & 5.8 \\
\hline
\end{tabular}

Table 4. Concentrations of released alkali cations $\left(\mathrm{K}^{+}, \mathrm{Na}^{+}\right.$and $\left.\mathrm{Li}^{+}\right)$during heavy metals removal $\left(\mathrm{C}_{\mathrm{R}}\right)$.

\begin{tabular}{|c|c|c|c|c|}
\hline Sample & Exchanged Cation & $\mathrm{C}_{\mathrm{R}}\left(\mathrm{Pb}^{2+}\right), \mathrm{meq} / 100 \mathrm{~g}$ & $\mathrm{C}_{\mathrm{R}}\left(\mathrm{Cd}^{2+}\right), \mathrm{meq} / 100 \mathrm{~g}$ & $\mathrm{C}_{\mathrm{R}}\left(\mathrm{Zn}^{2+}\right), \mathrm{meq} / 100 \mathrm{~g}$ \\
\hline AC@G-750- $\mathrm{N}_{2}-1.0-\mathrm{KOH}$ & $\mathrm{K}^{+}$ & 14.10 & 10.3 & 4.6 \\
\hline AC@G-750-N $2-1.0-\mathrm{NaOH}$ & $\mathrm{Na}^{+}$ & 2.0 & 1.6 & 1.1 \\
\hline AC@G-750-N $\mathrm{N}_{2}-1.0-\mathrm{LiOH}$ & $\mathrm{Li}^{+}$ & 1.8 & - & - \\
\hline AC@F-750-N $2-1.0-\mathrm{KOH}$ & $\mathrm{K}^{+}$ & 25.0 & 15.2 & 12.7 \\
\hline AC@F-750- $\mathrm{N}_{2}-1.0-\mathrm{NaOH}$ & $\mathrm{Na}^{+}$ & 2.1 & - & - \\
\hline AC@F-750- $\mathrm{N}_{2}-1.0-\mathrm{LiOH}$ & $\mathrm{Li}^{+}$ & 0.9 & - & - \\
\hline
\end{tabular}

The reason for differences in the removal of heavy metal cations between the sample activated with $\mathrm{KOH}$ and the other two may be found and explained by results presented in Table 4, where concentrations of the released cations in the solutions after heavy metals removal are given. It is clear that much higher amount of potassium was released in comparison with lithium or sodium which practically have not been detected. Non-stochiometric ratio between released cations and removed heavy metal ions may be an indication that heavy metal cations from solutions have been partially exchanged with potassium ions from activated carbon. Also, the amounts of bounded heavy metal cations for all adsorbents were much higher than amounts of released cations, meaning that significant parts of removed heavy metal cations have been bounded in some other ways and probably by chemisorption. The amount of potassium released from the sample obtained by $\mathrm{KOH}$ activation of fructose was much higher in comparison with amounts released from sample obtained from glucose, and that may be the reason for higher removed amount of all thee heavy metal cations from aqueous solutions although the fructose sample possess lower specific surface.

Under the same experimental conditions heavy metal removal was investigated using commercial activated carbon (C-AC) of known manufacturer. The results showed that C-AC adsorbed $\sim 68 \mathrm{meq} / 100 \mathrm{~g}$ lead ions, $\sim 13 \mathrm{meq} / 100 \mathrm{~g} \mathrm{Cd}^{2+}$ and $\sim 10 \mathrm{meq} / 100 \mathrm{~g} \mathrm{Zn}^{2+}$ what is very comparable with results obtained from samples activated with $\mathrm{KOH}$ for lead ions, while glucose and fructose $\mathrm{KOH}$ activated samples removed significantly higher amounts of cadmium and zinc ions. Also, in these investigations, after separation of the solid and liquid phase, final $\mathrm{pHs}$ were also measured. Results showed that final pHs were less than 6.6, meaning that all heavy metals were predominantly in the most dangerous $\left(\mathrm{X}^{2+}\right)$ form [63]. The presented results give just a part of information about capacities of investigated samples as well as about mechanism of removal of different heavy metals from aqueous solutions. However, for better understanding it is necessary to perform additional investigations and that will be the aim of our future work.

After experiments on model solutions, ACs samples were also tested for the treatment of real wastewater from the Grot mine, but in laboratory conditions. Experiments were performed on wastewater from the outlet pipe of the flotation facility (OF) and hydro-cyclone overflow (PHC) of the flotation tailings and adsorbents which previously showed the best heavy metals removal (AC@F-750- $\mathrm{N}_{2}-1.0-\mathrm{KOH}$ and AC@G-750- $\mathrm{N}_{2}-1.0-\mathrm{KOH}$ ). The results are shown in Tables 5 and 6.

As can be seen, the initial concentrations $\left(\mathrm{C}_{0}\right)$ of zinc, mercury, manganese, lead and nickel were very high and dangerous for human health (e.g., the content of lead was 61 times higher than maximal allowed concentration in drinking water $-0.01 \mathrm{mg} / \mathrm{dm}^{3}$ or 12 times higher than 
maximal allowed amount in water according to standard denoted as MPC1 in Table 5). On the other side, the concentrations of other investigated heavy metals were lower than maximally permissible concentrations according to listed standards (MPC1 and MPC2) in Tables 5 and 6.

Table 5. The concentrations of heavy metal cations in tailings wastewater before $\left(\mathrm{C}_{0}\right)$ and after treatment $\left(\mathrm{C}_{\mathrm{e}}\right)$ with AC@F-750- $\mathrm{N}_{2}-1.0-\mathrm{KOH}$.

\begin{tabular}{|c|c|c|c|c|c|c|c|c|}
\hline Pollutant & $\begin{array}{l}\mathrm{C}_{0, \mathrm{PHC}} \\
\mathrm{mg} / \mathrm{dm}^{3}\end{array}$ & $\begin{array}{l}\mathrm{C}_{\mathrm{e}, \mathrm{PHC}} \\
\mathrm{mg} / \mathrm{dm}^{3}\end{array}$ & $\begin{array}{c}\% \\
\text { Removal }\end{array}$ & $\begin{array}{c}\mathrm{C}_{0, \mathrm{OF}} \\
\mathrm{mg} / \mathrm{dm}^{3}\end{array}$ & $\begin{array}{c}\mathrm{C}_{\mathrm{e}, \mathrm{OF}} \\
\mathrm{mg} / \mathrm{dm}^{3}\end{array}$ & $\begin{array}{c}\% \\
\text { Removal }\end{array}$ & $\begin{array}{l}\mathrm{MPC1}{ }^{*} \\
\mathrm{mg} / \mathrm{dm}^{3}\end{array}$ & $\mathrm{MPC} 2 * *, \mathrm{mg} / \mathrm{dm}^{3}$ \\
\hline $\mathrm{Zn}$ & 0.338 & 0.14 & 59 & 0.269 & 0.121 & 55 & 0.2 & $0.024-0.8$ \\
\hline $\mathrm{Hg}$ & 2.568 & 1.980 & 23 & 1.304 & 0.978 & 25 & 0.001 & $0.00001-0.0003$ \\
\hline $\mathrm{Mn}$ & 3.069 & 1.921 & 37 & 2.568 & 1.721 & 33 & 0.1 & - \\
\hline $\mathrm{Cd}$ & $<0.045$ & $<0.045$ & - & $<0.045$ & $<0.045$ & - & 0.005 & $0.00006-0.006$ \\
\hline $\mathrm{Fe}$ & 0.075 & $<0.040$ & $>99$ & 0.179 & $<0.01$ & $>99$ & 0.3 & - \\
\hline $\mathrm{Ba}$ & $<0.007$ & $<0.007$ & - & $<0.007$ & $<0.007$ & - & - & - \\
\hline $\mathrm{Be}$ & $<0.004$ & $<0.004$ & - & $<0.004$ & $<0.004$ & - & - & - \\
\hline $\mathrm{Cu}$ & $<0.017$ & $<0.017$ & - & $<0.017$ & $<0.017$ & - & 0.1 & $0.0013-0.075$ \\
\hline $\mathrm{Al}$ & 0.065 & 0.054 & 17 & 0.023 & 0.018 & 22 & 0.2 & - \\
\hline $\mathrm{Mg}$ & 20.780 & 12.105 & 42 & 20.931 & 12.977 & 38 & 50 & - \\
\hline $\mathrm{Ca}$ & 98.859 & 74.304 & 25 & 117.983 & 73.768 & 29 & 200 & - \\
\hline $\mathrm{Si}$ & 6.340 & 3.221 & 49 & 6.810 & 3.337 & 51 & - & - \\
\hline $\mathrm{Pb}$ & 0.611 & 0.405 & 34 & 0.402 & 0.241 & 40 & 0.05 & $0.0017-0.075$ \\
\hline $\mathrm{Ni}$ & 0.068 & 0.055 & 19 & 0.072 & 0.057 & 21 & 0.05 & $0.0021-0.075$ \\
\hline $\mathrm{Cr}$ & 0.093 & 0.091 & 2 & 0.169 & 0.167 & 1 & 0.1 & $0.0025-0.03$ \\
\hline $\mathrm{Sr}$ & 0.604 & 0.503 & 17 & 0.496 & 0.422 & 15 & - & - \\
\hline
\end{tabular}

* MPC (maximum permissible concentrations) according to law of the Republic of Serbia, Regulations for Hazardous Substances in Waters, "Službeni glasnik SRS 31/82" and "Službeni list SRJ 42/98"; ** Target values and soil remediation intervention values and background concentrations soil/sediment and groundwater for metals. Dutch Target and Intervention Values, 2000 (the New Dutch List).

Table 6. The concentrations of heavy metal cations in tailings wastewater before $\left(\mathrm{C}_{0}\right)$ and after treatment (Ce) with AC@G-750-N $2-1.0-\mathrm{KOH}$.

\begin{tabular}{|c|c|c|c|c|c|c|c|c|}
\hline Pollutant & $\begin{array}{c}\mathrm{C}_{0, \mathrm{PHC}} \\
\mathrm{mg} / \mathrm{dm}^{3}\end{array}$ & $\begin{array}{l}\mathrm{C}_{\mathrm{e}, \mathrm{PHC}} \\
\mathrm{mg} / \mathrm{dm}^{3}\end{array}$ & $\begin{array}{c}\% \\
\text { Removal }\end{array}$ & $\begin{array}{c}\mathrm{C}_{0, \mathrm{OF}} \\
\mathrm{mg} / \mathrm{dm}^{3}\end{array}$ & $\begin{array}{c}\mathrm{C}_{\mathrm{e}, \mathrm{OF}} \\
\mathrm{mg} / \mathrm{dm}^{3}\end{array}$ & $\begin{array}{c}\% \\
\text { Removal }\end{array}$ & $\begin{array}{l}\mathrm{MPC1}^{*} \\
\mathrm{mg} / \mathrm{dm}^{3}\end{array}$ & $\mathrm{MPC} 2 * *, \mathrm{mg} / \mathrm{dm}^{3}$ \\
\hline $\mathrm{Zn}$ & 0.338 & 0.169 & 50 & 0.269 & 0.129 & 52 & 0.2 & $0.024-0.8$ \\
\hline $\mathrm{Hg}$ & 2.568 & 2.106 & 18 & 1.304 & 1.043 & 20 & 0.001 & $0.00001-0.0003$ \\
\hline $\mathrm{Mn}$ & 3.069 & 2.148 & 30 & 2.568 & 1.848 & 28 & 0.1 & - \\
\hline $\mathrm{Cd}$ & $<0.045$ & $<0.045$ & - & $<0.045$ & $<0.045$ & - & 0.005 & $0.00006-0.006$ \\
\hline $\mathrm{Fe}$ & 0.075 & $<0.040$ & $>99$ & 0.179 & $<0.040$ & $>99$ & 0.3 & - \\
\hline $\mathrm{Ba}$ & $<0.007$ & $<0.007$ & - & $<0.007$ & $<0.007$ & - & - & - \\
\hline $\mathrm{Be}$ & $<0.004$ & $<0.004$ & - & $<0.004$ & $<0.004$ & - & - & - \\
\hline $\mathrm{Cu}$ & $<0.017$ & $<0.017$ & - & $<0.017$ & $<0.017$ & - & 0.1 & $0.0013-0.075$ \\
\hline $\mathrm{Al}$ & 0.065 & 0.059 & 10 & 0.023 & 0.020 & 11 & 0.2 & - \\
\hline $\mathrm{Mg}$ & 20.780 & 13.507 & 35 & 20.931 & 12.977 & 38 & 50 & - \\
\hline $\mathrm{Ca}$ & 98.859 & 79.087 & 20 & 117.983 & 78.763 & 18 & 200 & - \\
\hline $\mathrm{Si}$ & 6.340 & 3.804 & 40 & 6.810 & 4.427 & 35 & - & - \\
\hline $\mathrm{Pb}$ & 0.611 & 0.428 & 30 & 0.402 & 0.285 & 29 & 0.05 & $0.0017-0.075$ \\
\hline $\mathrm{Ni}$ & 0.068 & 0.058 & 15 & 0.072 & 0.061 & 16 & 0.05 & $0.0021-0.075$ \\
\hline $\mathrm{Cr}$ & 0.093 & 0.091 & 2 & 0.169 & 0.166 & 2 & 0.1 & $0.0025-0.03$ \\
\hline $\mathrm{Sr}$ & 0.604 & 0.513 & 15 & 0.496 & 0.402 & 19 & - & - \\
\hline
\end{tabular}

* MDK (maximum allowed amount) according to law of the Republic of Serbia, Regulations for Hazardous Substances in Waters, "Službeni glasnik SRS 31/82" and "Službeni list SRJ 42/98"; ** Target values and soil remediation intervention values and background concentrations soil/sediment and groundwater for metals. Dutch Target and Intervention Values, 2000 (the New Dutch List).

After treatment of wastewater $\left(\mathrm{C}_{\mathrm{e}}\right)$ with AC@F-750- $\mathrm{N}_{2}-1.0-\mathrm{KOH}$ and AC@G-750- $\mathrm{N}_{2}-1.0-\mathrm{KOH}$, the content of all heavy metal cations was reduced. After treatment, the concentration of zinc was reduced by more than 50\%. The concentrations of other main pollutants: lead, mercury, manganese, nickel and strontium were also significantly reduced and after treatment, their concentrations were lowered by about 35, 20,33, 18 and 18\%, respectively. The concentrations of $\mathrm{Fe}, \mathrm{Cr}, \mathrm{Ca}$ and $\mathrm{Al}$ were also reduced after treatment with both adsorbents. However, fructose sample showed slightly better adsorption properties in comparison with glucose sample. These results indicate that both samples and especially AC@F-750- $\mathrm{N}_{2}-1.0-\mathrm{KOH}$ pose the potential to be used as a material for the production of 
collector filters for tailings. However, these results are just preliminary, and for practical applications, additional investigations on wastewater in real conditions will be done in future.

\subsubsection{Removal of Organic Dye from Aqueous Solution}

All samples prepared by activation with different hydroxides of the HTC-treated glucose and fructose were also tested for removal of MB from contaminated aqueous solutions. The adsorption measurements were carried out with the same concentrations of dye in solution $\left(50 \mathrm{mg}^{\mathrm{d}} \mathrm{dm}^{3}\right)$. The absorption spectra of dye solutions were collected after a certain time in interval 0-24 h, and two absorption maximums of wavelength $\lambda_{\max 1}=291 \mathrm{~nm}$ and $\lambda_{\max 2}=664 \mathrm{~nm}$ were used for measuring MB concentrations. The absorption spectra of MB solutions before and $24 \mathrm{~h}$ after introducing carbon powders are presented in Figure 6a and b.
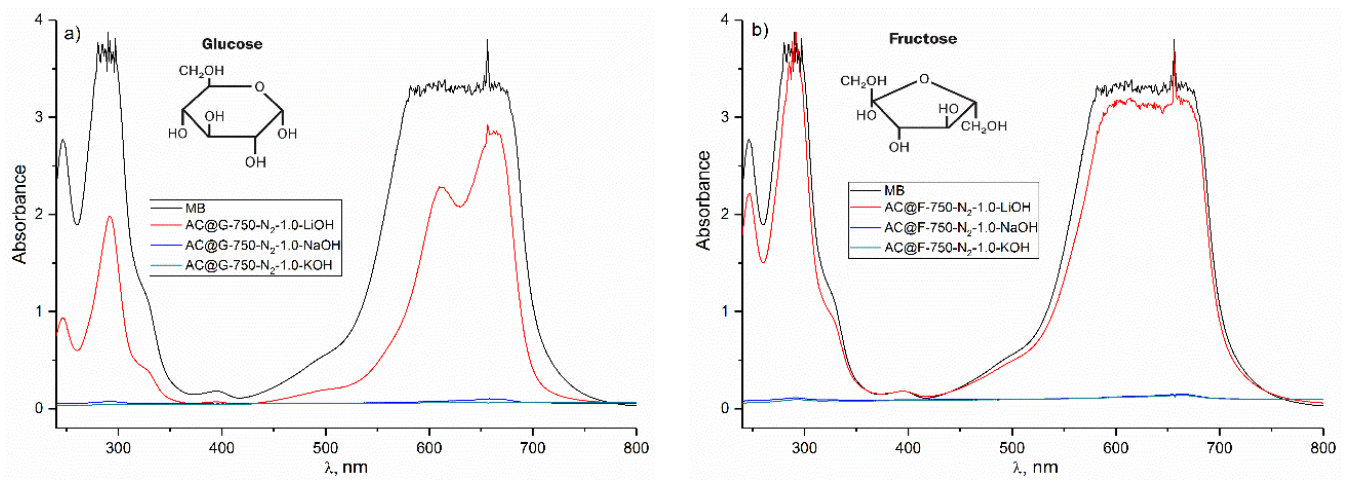

Figure 6. Absorption spectra of MB solutions $\left(50 \mathrm{mg} / \mathrm{dm}^{3}\right)$ before and $24 \mathrm{~h}$ after introducing of activated carbons: (a) glucose and (b) fructose. The solid/liquid ratio was $25 \mathrm{mg} / 25 \mathrm{~cm}^{3}$.

As it can be seen from absorption spectra (Figure 6), the intensity of the characteristic bands for $\mathrm{MB}$ significantly decreased after treating of the solutions with glucose (Figure 6a) and fructose (Figure 6b) samples activated with $\mathrm{NaOH}$ and $\mathrm{KOH}$, indicating that significant amount of $\mathrm{MB}$ was removed from solutions after $24 \mathrm{~h}$. However, samples activated with $\mathrm{LiOH}$ showed very low adsorption of $\mathrm{MB}$. From that reason, $\mathrm{LiOH}$ activated samples were not further considered. Significant lower adsorption obtained by samples activated with $\mathrm{LiOH}$ may be consequence of very low mesopore specific surface area. Similar dependence between mesopores specific surface and MB removal have shown by other authors [59] for adsorption of MB on activated carbon prepared from Tamarind Seeds by activation with $\mathrm{KOH}$, as well as, with results published by Kim et al. [64] for organic dyes removal on hierarchical nanoporous $\mathrm{MnO}$.

Figure 7 illustrated the effect of contact time on removal of $\mathrm{MB}$ from aqueous solution by glucose and fructose samples activated with $\mathrm{NaOH}$ and $\mathrm{KOH}$. As can be seen, the $\mathrm{MB}$ removal increased with an increase in contact time. For glucose, the removal was most rapid in the first 10 min for $\mathrm{KOH}$ and $40 \mathrm{~min}$ for $\mathrm{NaOH}$ activated sample, while for fructose the removal was rapid in the first $30 \mathrm{~min}$ for both hydroxides and then it tended to level thereafter, proceeding at a slower rate until saturation was obtained. For all samples, it was noticed that solutions were almost colorless after 40 min, meaning that almost all amounts of MB were removed from the solution. From the presented results it may be concluded that, under applied experimental conditions, the removal of MB from aqueous solutions was very fast for investigated samples ( $\mathrm{KOH}$ and $\mathrm{NaOH}$ activated), but slightly better results were obtained for samples from glucose. Since, there were no significant changes in amount of removed MB from the solution after $140 \mathrm{~min}$, on diagrams are shown time dependencies only for the first $140 \mathrm{~min}$. 

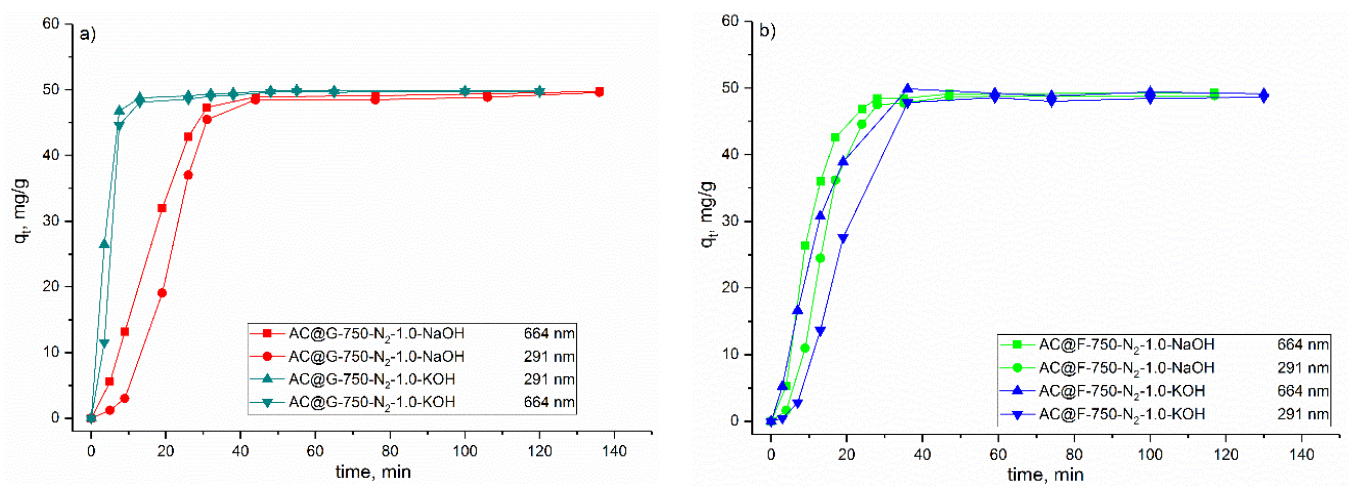

Figure 7. Removed amount of $\mathrm{MB}$ as a function of the contact time: (a) glucose; (b) fructose.

From the presented results, it can be concluded that samples obtained by activating with $\mathrm{NaOH}$ exhibit a high degree of removal of MB from the aqueous solution and its removal are comparable to those obtained with the $\mathrm{KOH}$-activated samples. However, the yield for the production of $\mathrm{NaOH}$ activated samples $(\sim 7 \%)$ is almost two times lower in comparison with $\mathrm{KOH}$ activation $(\sim 14 \%)$, because of which the advantage can be given to $\mathrm{KOH}$ activated samples and these samples were further analyzed.

Obtained results for $\mathrm{MB}$ removal by $\mathrm{KOH}$ activated glucose and fructose samples (measured at $664 \mathrm{~nm}$ ) were then fitted to different kinetic model: pseudo I, pseudo II and Elovich model, which linear forms are given in Equations (1)-(3) [65], respectively:

$$
\begin{gathered}
\ln \frac{\mathrm{q}_{\mathrm{t}}}{\mathrm{q}_{\mathrm{e}}}=\mathrm{k}_{1} \mathrm{t} \\
\frac{\mathrm{t}}{\mathrm{q}_{\mathrm{t}}}=\frac{1}{\mathrm{k}_{2} \cdot \mathrm{q}_{\mathrm{e}}^{2}}+\frac{1}{\mathrm{q}_{\mathrm{e}}} \mathrm{t} \\
\mathrm{q}_{\mathrm{t}}=\mathrm{b} \cdot \ln (\mathrm{ab})+\mathrm{b} \cdot \ln \mathrm{t}
\end{gathered}
$$

where, $\mathrm{q}_{\mathrm{e}}$ and $\mathrm{q}_{\mathrm{t}}(\mathrm{mg} / \mathrm{g})$ are removed amounts of MB in equilibrium and time $\mathrm{t}(\mathrm{min}), \mathrm{k}_{1}(1 / \mathrm{min})$ and $\mathrm{k}_{2}(\mathrm{~g} /(\mathrm{mg} \cdot \mathrm{min}))$ are constants of rate for pseudo I and II order, respectively, a $(\mathrm{mg} /(\mathrm{g} / \mathrm{min}))$ is initial rate of MB removal and $\mathrm{b}(\mathrm{g} / \mathrm{mg})$ is a factor which indicated the degree of coverage of the surface of the adsorbent and the activation energy of the chemisorption.

The coefficients of correlation $\left(\mathrm{R}^{2}\right)$ for pseudo I, pseudo II order models and Elovich model are: $0.35,0.98$ and 0.89 , respectively for fructose sample activated with $\mathrm{KOH}$ and $0.52,0.99$ and 0.82 , respectively for glucose sample activated with $\mathrm{KOH}$. Due to low values of the $\mathrm{R}^{2}$, characteristic parameters of the pseudo I order and Elovich models were not calculated and only parameters of the pseudo II order model and characteristic linear curves are presented in Figure 8 and Table 7. Also, initial rate $\left(\mathrm{h}=\mathrm{k}_{2} \cdot \mathrm{q}_{\mathrm{e}}{ }^{2}\right)$ was determined for both adsorbents and results are presented in Table 7 .

From results presented in Figure 8 and Table 7, good fitting, high values of $R^{2}$ and good agreement of experimental and calculated values of $\mathrm{q}_{\mathrm{e}}$ were obtained, meaning that the Pseudo II order model effectively described the kinetic of removal of the $\mathrm{MB}$ from aqueous solutions using $\mathrm{KOH}$ activated samples obtained from glucose and fructose. Both, initial rate (h) as well as rate constant $\left(\mathrm{k}_{2}\right)$, were much higher for removal MB by AC@G $-750-\mathrm{N}_{2}-1.0-\mathrm{KOH}$, indicating much favorable adsorption of $\mathrm{MB}$ than on AC@F-750- $\mathrm{N}_{2}-1.0-\mathrm{KOH}$. The reason for that trend may be higher values of the specific surface $\left(\mathrm{S}_{\mathrm{BET}}\right.$ and $\left.\mathrm{S}_{\text {meso }}\right)$ as well as greater availability of the active centers for glucose in comparison with fructose sample.

Fitting of the experimental results with different kinetic models may give information about that at which way the interaction between MB and adsorbents takes place. The best fitting Pseudo II order model for both investigated samples give an indication that chemisorption, which include valence 
forces through sharing or exchange electrons, is included in MB removal and also that this process is the rate limiting (the slowest) step $[38,66]$. Significant lower values of rate constants (initial rate (h) as well as rate constant $\left(\mathrm{k}_{2}\right)$ ) for fructose sample means that, the chemisorption takes place in much greater extent on this sample than on the sample obtained from glucose.

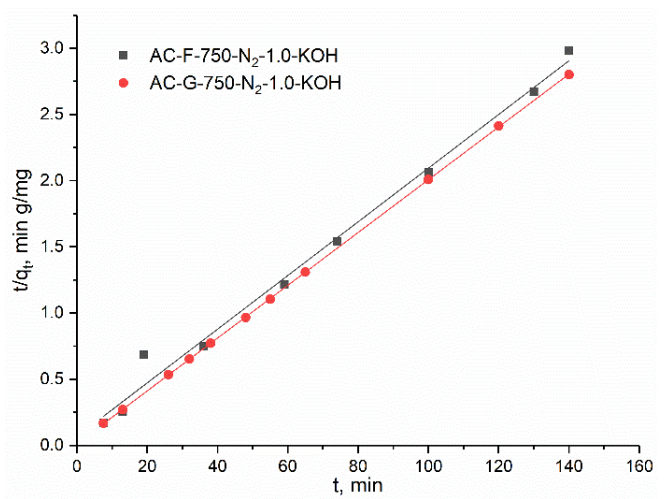

Figure 8. Linear fits of Pseudo II order kinetic model for $\mathrm{KOH}$ activated glucose and fructose samples.

Table 7. Characteristic parameters of the Pseudo II order kinetic model for MB removal.

\begin{tabular}{ccc}
\hline Kinetic Parameter & AC@G-750-N2-1.0-KOH & AC@F-750-N2-1.0-KOH \\
\hline $\mathrm{q}_{\mathrm{e}, \text { exper }}(\mathrm{mg} / \mathrm{g})$ & 49.71 & 49.82 \\
$\mathrm{q}_{\mathrm{e}}(\mathrm{mg} / \mathrm{g})$ & 50.00 & 50.00 \\
$\mathrm{~h} / \mathrm{g} /(\mathrm{mg} \cdot \mathrm{min})$ & 100.00 & 14.28 \\
$\mathrm{k}_{2}, \mathrm{~g} /(\mathrm{mg} \cdot \mathrm{min})$ & $40.0 \times 10^{-3}$ & $5.7 \times 10^{-3}$ \\
$\mathrm{R}^{2}$ & 0.99 & 0.98 \\
\hline
\end{tabular}

In order to determine influence of the processes on the surface and the diffusion on the total adsorption rate, and to get additional information about binding mechanism of MB on both adsorbents, the intra-particle diffusion model was also applied. The mathematic form of the diffusion model is given in Equation (4) [65]:

$$
\mathrm{q}_{\mathrm{t}}=\mathrm{I}+\mathrm{k}_{\mathrm{D}} \mathrm{t}^{1 / 2}
$$

where $\mathrm{q}_{\mathrm{t}}(\mathrm{mg} / \mathrm{g})$ is adsorbed amount of MB in time $\mathrm{t}(\mathrm{min}), \mathrm{k}_{\mathrm{D}}\left(\mathrm{mg} /\left(\mathrm{g} \cdot \mathrm{min}^{1 / 2}\right)\right)$ is the diffusion constant and I is a constant and equal to the intercept on $y$-axis. The results are presented in Figure 9 and Table 8.
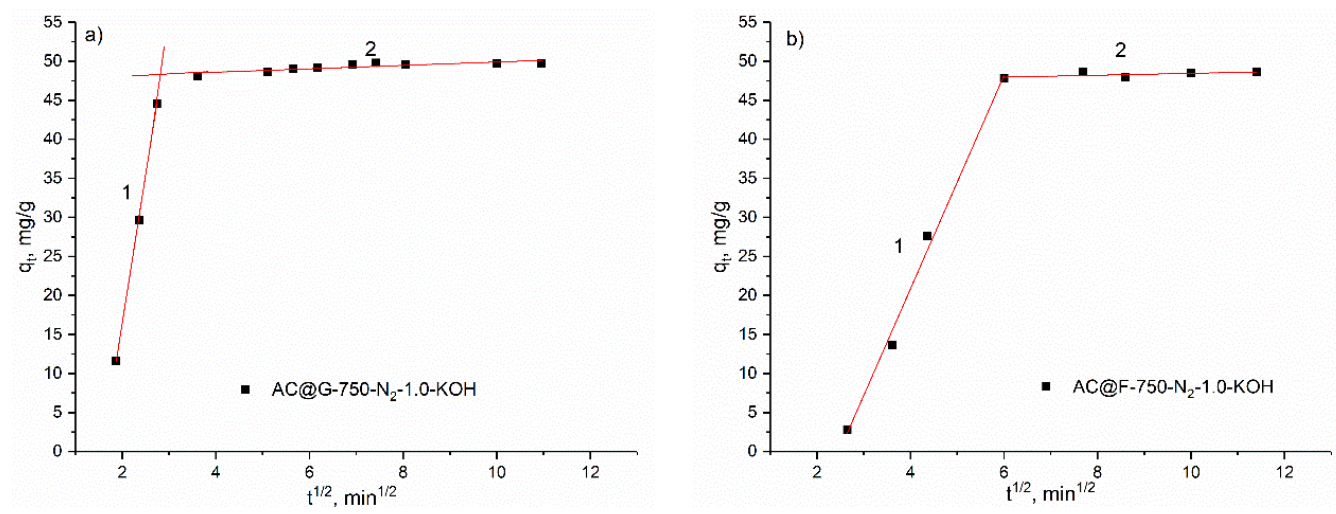

Figure 9. Intra-particle diffusion model for (a) glucose and (b) fructose activated samples.

According to this model, the adsorption process in general includes three processes: (1) migrating the pollutants from the solution to the surface of the adsorbent and forming the film on the surface; 
(2) adsorption at appropriate active centers on the surface; (3) diffusion into internal channels and vacancies. If the curves pass through zero and are linear in the entire time interval, only the diffusion influence on the total rate of the pollutant removal. Otherwise, in addition to diffusion, all the mentioned processes occur, and the overall rate is influenced by the processes on the surface and the diffusion [67].

Table 8. Characteristic parameters of the intra-particle diffusion kinetic model for MB removal.

\begin{tabular}{|c|c|c|c|c|}
\hline \multirow{2}{*}{ Time Interval } & \multicolumn{2}{|c|}{ AC@G-750- $\mathrm{N}_{2}-1.0-\mathrm{KOH}$} & \multicolumn{2}{|c|}{ AC@F-750-N ${ }_{2}-1.0-\mathrm{KOH}$} \\
\hline & $\mathbf{R}^{2}$ & $\mathrm{k}_{\mathrm{D}}, \mathrm{mg} /\left(\mathrm{g} \cdot \min ^{1 / 2}\right)$ & $\mathbf{R}^{2}$ & $\mathrm{k}_{\mathrm{D}}, \mathrm{mg} /\left(\mathrm{g} \cdot \mathrm{min}^{1 / 2}\right)$ \\
\hline 1 & 0.99 & 38.07 & 0.99 & 13.66 \\
\hline 2 & 0.99 & 0.22 & 0.99 & 0.12 \\
\hline
\end{tabular}

As may be seen from Figure 9, for both adsorbents, curves do not pass through zero and are not linear in all time intervals, which means that different processes are included in MB removal. The largest part of the $\mathrm{MB}$ was removed in the first time interval (1) where the highest values of the $\mathrm{k}_{\mathrm{D}}$ were determined $\left(\sim 38\right.$ and $\sim 14 \mathrm{mg} /\left(\mathrm{g} \cdot \mathrm{min}^{1 / 2}\right)$, for AC@G-750- $\mathrm{N}_{2}-1.0-\mathrm{KOH}$ and AC@F-750- $\mathrm{N}_{2}-1.0-\mathrm{KOH}$, respectively), meaning that $\mathrm{MB}$ was mainly removed by processes which include migrating the $\mathrm{MB}$ from the solution to the surface of the adsorbents, forming film on the surfaces and adsorption at appropriate active centers on the surfaces. Very low slopes and $k_{D}$ values obtained for both adsorbents in second time interval indicate that a very small amount of the MB was removed from solution by diffusion into internal channels and vacancies. Since that almost all amounts of $\mathrm{MB}$ were removed from the solution by processes which occur on the surface of the adsorbents, it can be concluded that these processes are the most responsible for the overall reaction rate and diffusion through the internal channels and the vacancies does not significantly affect the entire process. Similar conclusions were made by other authors for removal of methylene blue by mango seed kernel powder [68] or by activated carbon developed from Ficus carica bast [38].

For applied experimental conditions it was not possible to reach a conclusion regarding which sample possesses better adsorption capacity for $\mathrm{MB}$, since both samples removed almost $100 \%$ of the MB from aqueous solution. From that reason, samples were additionally tested for MB removal. All experimental conditions were the same as in previous experiments, but with significant higher initial MB concentration $\left(200 \mathrm{mg} / \mathrm{dm}^{3}\right)$. Results showed that after $24 \mathrm{~h}$ final $\mathrm{pH}$ was 6.3 for AC@F-750- $\mathrm{N}_{2}-1.0-\mathrm{KOH}$ and 7.2 for AC@G-750- $\mathrm{N}_{2}-1.0-\mathrm{KOH}$. Removed amount of the MB was $61 \mathrm{mg} / \mathrm{g}$ for AC@G-750- $\mathrm{N}_{2}-1.0-\mathrm{KOH}$, while for the fructose sample a significantly higher amount of adsorbed MB was obtained and was $197 \mathrm{mg} / \mathrm{g}$. The possible reason for a higher capacity and slower MB binding rate for the sample AC@F-750- $\mathrm{N}_{2}-1.0-\mathrm{KOH}$ could be higher density but lower accessibility of active centers containing carbon which are responsible for MB removal.

The $\mathrm{pH}$ was also measured for suspensions of both adsorbents in clear distilled water $\left(25 \mathrm{mg} / 25 \mathrm{~cm}^{3}\right)$ for a time period of $150 \mathrm{~min}$. The results showed that $\mathrm{pH}$ was 8.8 for fructose and 10.3 for the glucose $\mathrm{KOH}$ activated sample. Since the fructose sample showed much better removal of $\mathrm{MB}$, even possessing lower $\mathrm{pH}$ (lower amount of -OH groups at surface) in comparison with $\mathrm{KOH}$ activated glucose, it may be concluded that main bounding of the MB occurs at active centers containing carbon what is in agreement with Pseudo II order kinetic model. On the other side, lowering of the $\mathrm{pH}$ after $\mathrm{MB}$ removals by both adsorbents indicate that $-\mathrm{OH}$ groups at their surfaces are also responsible for MB removal. So finally, it may be said that bounding of the MB occurs on both, active centers containing carbon and -OH groups at surfaces of both adsorbents.

Table 9 showed comparison of the removed amount of MB from aqueous solutions obtained by using different environmental-friendly adsorbents. It may be seen, that AC@G $-750-\mathrm{N}_{2}-1.0-\mathrm{KOH}$ is very comparable with results obtained by other authors, but, on the other side, AC@F-750- $\mathrm{N}_{2}-1.0-\mathrm{KOH}$ removed a significantly higher amount of MB. 
Table 9. Comparison of the removed amount of MB from aqueous solutions obtained using different environmental-friendly adsorbents.

\begin{tabular}{cccc}
\hline Adsorbent & Dye Name & Adsorption Capacity & Reference \\
\hline Orange peel & MB & 18.6 & {$[69]$} \\
Peanut hull & MB & 68.0 & {$[70]$} \\
Rice husk & MB & 40.6 & {$[71]$} \\
Cherry Sawdust & MB & 39.8 & {$[72]$} \\
Wheat shells & MB & 16.6 & {$[73]$} \\
Walnut shell & MB & 51.6 & {$[26]$} \\
AC@G-750- $\mathrm{N}_{2}-1.0-\mathrm{KOH}$ & $\mathrm{MB}$ & 61.0 & This study \\
AC@F-750- $\mathrm{N}_{2}-1.0-\mathrm{KOH}$ & $\mathrm{MB}$ & 197.0 & This study \\
\hline
\end{tabular}

\section{Conclusions}

Results obtained in this study may be summarized as:

- Samples obtained from glucose pose an amorphous structure, while in samples obtained from fructose besides being amorphous, the presence of crystal phases $\left(\mathrm{X}_{2} \mathrm{CO}_{3}\right.$ and oxides $\left.\mathrm{X}_{2} \mathrm{O}\right)$ was also detected.

- For precursors, glucose and fructose, the elementary analysis showed that the carbon content was much higher after activation with $\mathrm{KOH}$ and $\mathrm{NaOH}$.

- Samples activated with $\mathrm{KOH}$ and $\mathrm{NaOH}$ pose much better textural properties in comparison with samples activated with $\mathrm{LiOH}$.

- After treating of carbon samples with $\mathrm{KOH}$, the changing and destroying of their spherical shapes and microspheres were noticed in the case of both glucose and fructose precursors. On the contrary, carbon samples treated with $\mathrm{LiOH}$ and $\mathrm{NaOH}$ maintained their microspherical structures but with different particle size for the whole order of size.

- All investigated samples showed high affinity for lead cadmium and zinc ions. Samples activated with $\mathrm{KOH}$ showed better removal of all three heavy metal cations in comparison with those activated with $\mathrm{LiOH}$ and $\mathrm{NaOH}$. The best removal was obtained for AC@F-750- $\mathrm{N}_{2}-1.0-\mathrm{KOH}$.

- Non-stochiometric ratio between released cations and removed heavy metals ions indicated that heavy metal cations from solutions have been partially exchanged with $\mathrm{K}^{+}, \mathrm{Na}^{+}$or $\mathrm{Li}^{+}$ions from activated carbon. Much higher amounts of bounded heavy metal cations for all adsorbents than amounts of released cations, indicate that significant part of removed heavy metal cations have been bounded by some other ways, probably by chemisorption.

- Results of wastewater treatment in the laboratory conditions indicate that both glucose and fructose $\mathrm{KOH}$ activated samples, especially AC@F-750- $\mathrm{N}_{2}-1.0-\mathrm{KOH}$ pose the potential to be used as materials for the production of collector filters for tailings.

- Results of MB removal indicating that significant amount of MB was removed from solutions after treating of the solution with both glucose and fructose $\mathrm{KOH}$ and $\mathrm{NaOH}$ activated samples.

- Results also showed that kinetic removal of $\mathrm{MB}$ from water solutions by $\mathrm{KOH}$ and $\mathrm{NaOH}$ activated glucose and fructose samples was very fast and may be described with the Pseudo II order model.

- Fitting of the results with intra-particle diffusion kinetic model indicate total rate is not affected only by diffusion, but also by processes on the surface and diffusion through the internal channels and the vacancies do not significantly effect the entire process.

Author Contributions: S.K. participated in conceiving and designing experiments, characterization of samples, analyzing of results and paper writing; M.K. participated in writing paper, performing experiments of heavy metals adsorption, analyzing of results; M.P. performed experiments of methylene blue adsorption and analyzed of the obtained results and participated in writing paper; V.D. performed experiments related with determination of textural properties and participated in explaining results; B.K. participated in experiments related with synthesis of the samples and in explaining of the obtained results; M.M. participated in performing experiments related with elemental analyses and ICP measurements; I.R. provided samples from flotation tailing and contributed in analyzing of the SEM results; M.S. participated in conceiving and designing experiments, paper writing and contributed in analyzing of results. 
Acknowledgments: The financial support of this research work was provided by the Ministry of Education and Science of the Republic of Serbia, Projects III45005, III45012, 172015, TR34013.

Conflicts of Interest: The authors declare no conflict of interest.

\section{References}

1. Vukojević Medvidović, N.; Perić, J.; Trgo, M. Column performance in lead removal from aqueous solutions by fixed bed of natural zeolite-clinoptilolite. Sep. Purif. Technol. 2006, 49, 237-244. [CrossRef]

2. Fu, F.; Wang, Q. Removal of heavy metal ions from wastewaters: A review. J. Environ. Manag. 2011, 92,407-418. [CrossRef] [PubMed]

3. Hamidpour, M.; Kalbasi, M.; Afyuni, M.; Shariatmadari, H.; Holm, P.E.; Hansen, H.C. Sorption hysteresis of $\mathrm{Cd}(\mathrm{II})$ and $\mathrm{Pb}(\mathrm{II})$ on natural zeolite and bentonite. J. Hazard. Mater. 2010, 181, 686-691. [CrossRef] [PubMed]

4. Milentijević, G.; Nedeljković, B.; Lekić, M.; Nikić, Z.; Ristović, I.; Djokić, J. Application of a Method for intelligent multi-criteria analysis of the environmental impact of tailing ponds in northern Kosovo and Metohija. Energies 2016, 9, 935. [CrossRef]

5. Institute IMS ad. Certificate of Determining the Nature of Waste CPO No. 016/07 (2007); Institute IMS ad: Belgrade, Serbia, 2007.

6. Björklunda, K.; Lia, L. Adsorption of organic stormwater pollutants onto activated carbon from sewage sludge. J. Environ. Manag. 2017, 197, 490-497. [CrossRef] [PubMed]

7. Lladó, J.; Gil, R.; Lao-Luque, C.; Solé-Sardans, M.; Fuente, E.; Ruiz, B. Highly microporous activated carbons derived from biocollagenic wastes of the leather industry as adsorbents of aromatic organic pollutants in water. J. Environ. Chem. Eng. 2017, 5, 2090-2100. [CrossRef]

8. Khan, T.A.; Singh, V.V.; Kumar, D. Removal of some basic dyes from artificial textile wastewater by adsorption on Akash Kinari coal. J. Sci. Ind. Res. 2004, 63, 355-364.

9. Chen, L.; Ramadan, A.; Lv, L.; Shao, W.; Luo, F.; Chen, J. Bio sorption of methylene blue from aqueous solution using lawny grass modified with citric acid. J. Chem. Eng. Data 2011, 56, 3392-3399. [CrossRef]

10. Hameed, B.H.; Ahmad, A.A. Batch adsorption of methylene blue from aqueous solution by garlic peel, an agricultural waste biomass. J. Hazard. Mater. 2009, 164, 870-875. [CrossRef] [PubMed]

11. Kumar, P.S.; Ramalingam, S.; Sathishkumar, K. Removal of methylene blue dye from aqueous solution by activated carbon prepared from cashew nut shell as a new low-cost adsorbent. Korean J. Chem. Eng. 2011, 28, 149-155. [CrossRef]

12. Mittal, A.; Malviya, A.; Kaur, D.; Mittal, J.; Kurup, L. Studies on the adsorption kinetics and isotherms for the removal and recovery of methyl orange from wastewaters using waste materials. J. Hazard. Mater. 2007, 148, 229-240. [CrossRef] [PubMed]

13. Leechart, P.; Nakbanpote, W.; Thiravetyan, P. Application of "waste" wood-shaving bottom ash for adsorption of azo reactive dye. J. Environ. Manag. 2009, 90, 912-920. [CrossRef] [PubMed]

14. Bhatnagar, A.; Jain, A.K. A comparative adsorption study with different industrial wastes as adsorbents for the removal of cationic dyes from water. J. Colloid Interface Sci. 2005, 281, 49-55. [CrossRef] [PubMed]

15. Pezoti, O.J.; Cazetta, A.L.; Souza, I.P.A.F.; Bedin, K.C.; Martins, A.C.; Silva, T.L.; Almeida, V.C. Adsorption studies of Methylene Blue onto $\mathrm{ZnCl}_{2}$-activated carbon produced from Buriti shells (Mauritia flexuosa $\mathrm{L}$.). J. Ind. Eng. Chem. 2014, 20, 4401-4407. [CrossRef]

16. Gupta, V.K. Application of low-cost adsorbents for dye removal: A review. J. Environ. Manag. 2009, 90, 2313-2342. [CrossRef] [PubMed]

17. Hosseini, S.; Ali Khan, M.; Malekbala, M.R.; Cheah, W.; Choong, T. Carbon coated monolith, a mesoporous material for the removal of methyl orange from aqueous phase: Adsorption and desorption studies. Chem. Eng. J. 2011, 171, 1124-1131. [CrossRef]

18. Ngarmkam, W.; Sirisathitkul, C.; Phalakornkule, C. Magnetic composite prepared from palm shell-based carbon and application for recovery of residual oil from POME. J. Environ. Manag. 2011, 92, 472-479. [CrossRef] [PubMed]

19. Panneerselvam, P.; Morad, N.; Tan, K.A. Magnetic nanoparticle $\left(\mathrm{Fe}_{3} \mathrm{O}_{4}\right)$ impregnated onto tea waste for the removal of nickel (II) from aqueous solution. J. Hazard. Mater. 2011, 186, 160-168. [CrossRef] [PubMed]

20. Reza, R.A.; Ahmaruzzaman, M. A novel synthesis of $\mathrm{Fe}_{2} \mathrm{O}_{3}$ activated carbon composites and its exploitation for the elimination of carcinogenic textile dye from aqueous phase. RSC Adv. 2015, 5, 10575-10586. [CrossRef] 
21. Cataldo, S.; Muratore, N.; Orecchio, S. Enhancement of adsorption ability of calcium alginate gel beads towards Pd(II) ion. A kinetic and equilibrium study on hybrid Laponite and Montmorillonite-alginate gel beads. Appl. Clay Sci. 2015, 118, 162-170. [CrossRef]

22. Babel, S.; Kurniawan, T.A. Low-cost adsorbents for heavy metals uptake from contaminated water: A review. J. Hazard. Mater. 2003, 97, 219-243. [CrossRef]

23. Wang, Y.-H.; Lin, S.-H.; Juang, R.-S. Removal of heavy metal ions from aqueous solutions using various low-cost adsorbents. J. Hazard. Mater. 2003, 102, 291-302. [CrossRef]

24. Ma, Y.; Lv, L.; Guo, Y.; Fu, Y.; Shao, Q.; Wu, T.; Guo, S.; Sun, K.; Guo, X.; Wujcik, E.; et al. Porous lignin-based poly (acrylic acid)/organo-montmorillonite nanocomposites: Swelling behaviors and rapid removal of $\mathrm{Pb}$ (II) ions. Polymer 2017, 128, 12-23. [CrossRef]

25. Bukallah, S.B.; Rauf, M.A.; AlAli, S.S. Removal of Methylene Blue from aqueous solution by adsorption on sand. Dyes Pigments 2007, 74, 85-87. [CrossRef]

26. Tang, R.; Dai, C.; Li, C.; Liu, W.; Gao, S.; Wang, C. Removal of methylene blue from aqueous solution using agricultural residue walnut shell: Equilibrium, kinetic, and thermodynamic studies. J. Chem. 2017, 2017, 1-10. [CrossRef]

27. Tahir, H.; Sultan, M.; Jahanzeb, Q. Removal of basic dye methylene blue by using bioabsorbents Ulva lactuca and Sargassum. Afr. J. Biotechnol. 2008, 7, 2649-2655.

28. Sun, K.; Fan, R.; Zhang, X.; Zhang, Z.; Shi, Z.; Wang, N.; Xie, P.; Wang, Z.; Fan, G.; Liu, H.; et al. An overview of metamaterials and their achievements in wireless power transfer. J. Mater. Chem. C 2018, 6, 2925-2943. [CrossRef]

29. Li, Y.; Zhou, B.; Zheng, G.; Liu, X.; Li, T.; Yan, C.; Cheng, C.; Dai, K.; Liu, C.; Shena, C.; et al. Continuously prepared highly conductive and stretchable SWNTs/MWNTs synergistically composited electrospun thermoplastic polyurethane yarns for wearable sensing. J. Mater. Chem. C 2018, 6, 2258-2269. [CrossRef]

30. Guan, X.; Zheng, G.; Dai, K.; Liu, C.; Yan, X.; Shen, C.; Guo, Z. Carbon Nanotubes-Adsorbed Electrospun PA66 Nanofiber Bundles with Improved Conductivity and Robust Flexibility. ACS Appl. Mater. Interfaces 2016, 8, 14150-141559. [CrossRef] [PubMed]

31. Liu, H.; Huang, W.; Yang, X.; Dai, K.; Zheng, G.; Liu, C.; Shen, C.; Yan, X.; Guob, J.; Guo, Z. Organic vapor sensing behaviors of conductive thermoplastic polyurethane-graphene nanocomposites. J. Mater. Chem. C 2016, 4, 4459-4469. [CrossRef]

32. Liu, H.; Dong, M.; Huang, W.; Gao, J.; Dai, K.; Guo, J.; Zheng, G.; Liu, C.; Shen, C.; Guo, Z. Lightweight conductive graphene/thermoplastic polyurethane foams with ultrahigh compressibility for piezoresistive sensing. J. Mater. Chem. C 2017, 5, 73-83. [CrossRef]

33. Liu, H.; Li, Y.; Dai, K.; Zheng, G.; Liu, C.; Shen, C.; Yan, X.; Guo, J.; Guo, Z. Electrically conductive thermoplastic elastomer nanocomposites at ultralow graphene loading levels for strain sensor applications. J. Mater. Chem. C 2016, 4, 157-166. [CrossRef]

34. Libbrecht, A.W.; Verberckmoes, A.; Thybaut, J.; Van Der Voort, P.; De Clercq, J. Soft templated mesoporous carbons: Tuning the porosity for the adsorption of large organic pollutants. Carbon 2017, 116, 528-546. [CrossRef]

35. Huang, J.; Cao, Y.; Shao, Q.; Peng, X.; Guo, Z. Magnetic nanocarbon adsorbents with enhanced hexavalent chromium removal: Morphology dependence of fibrillar vs particulate structures. Ind. Eng. Chem. Res. 2017, 56, 10689-10701. [CrossRef]

36. Joo, J.B.; Kim, Y.J.; Kim, W.; Kim, P.; Yi, J. Simple synthesis of graphitic porous carbon by hydrothermal method for use as a catalyst support in methanol electro-oxidation. Catal. Commun. 2008, 10, 267-271. [CrossRef]

37. Isao, M.; Cha-Hun, K.; Yozo, K. Anodic Performance and Insertion Mechanism of Hard Carbons Prepared from Synthetic Isotropic Pitches. Carbon 2001, 39, 399-410.

38. Pathania, D.; Sharma, S.; Singh, P. Removal of methylene blue by adsorption onto activated carbon developed from Ficus carica bast. Arab. J. Chem. 2017, 10, 1445-1451. [CrossRef]

39. Geçgel, Ü.; Özcan, G.; Gürpınar, G.C. Removal of Methylene Blue from aqueous solution by activated carbon prepared from pea shells (Pisum sativum). J. Chem. 2013. [CrossRef]

40. Liu, L.; Lin, Y.; Liu, Y.; Zhu, H.; He, Q. Removal of methylene blue from aqueous solutions by sewage sludge based granular activated carbon: Adsorption equilibrium, kinetics, and thermodynamics. J. Chem. Eng. Data 2013, 58, 2248-2253. [CrossRef] 
41. Barrett, E.P.; Joyner, L.G.; Halenda, P.P. The determination of pore volume and area distributions in porous substances. I. Computations from nitrogen isotherms. J. Am. Chem. Soc. 1951, 73, 373-380. [CrossRef]

42. Kaneko, K.; Ishii, C.; Kanoh, H.; Hanzawa, Y.; Setoyama, N.; Suzuki, T. Characterization of porous carbons with high resolution $\alpha$ s-analysis and low temperature magnetic susceptibility. Adv. Colloid Interface. Sci. 1998, 76-77, 295-320. [CrossRef]

43. Weber, W.H.; Hass, K.C.; Mcbride, J.R. Raman study of $\mathrm{CeO}_{2}$ : Second-order scattering, lattice dynamics, and particle-size effects. Phys. Rev. B 1993, 48, 178-185. [CrossRef]

44. Tsunekawa, S.; Wang, J.-T.; Kawazoe, Y. Lattice constants and electron gap energies of nano- and subnano-sized cerium oxides from the experiments and first-principles calculations. J. Alloy. Compd. 2006, 408-412, 1145-1148. [CrossRef]

45. Sing, K.S.W.; Everett, D.H.; Haul, R.A.W.; Moscou, L.; Pierotti, R.A.; Rouquerol, J.; Siemieniewska, T. Reporting physisorption data for gas/solid systems with special reference to the determination of surface area and porosity. Pure Appl. Chem. 1985, 57, 603-619. [CrossRef]

46. International Organization for Standardization. SRPS ISO 5667-10:2007, Water Quality. Taking of Sample. Part 10: Guidance on Wastewaters Sampling; International Organization for Standardization: Geneva, Switzerland, 2007.

47. Teh, S.J.; Hamid, S.B.A.; Lai, C.W.; Lim, S.Y. $\mathrm{ZnCl}_{2} / \mathrm{NaCl}$-catalysed hydrothermal carbonization of glucose and oil palm shell fiber. Nanosci. Notechnol. Lett. 2015, 7, 611-615. [CrossRef]

48. Kubo, S.; Demir-Cakan, R.; Zhao, L.; White, R.J.; Titirici, M.M. Porous carbohydrate-based materials via hard templating. ChemSusChem 2010, 3, 188-194. [CrossRef] [PubMed]

49. Jin, Y.Z.; Gao, C.; Hsu, W.K.; Zhu, Y.Q.; Huczko, A.; Bystrzejewski, M.; Roe, M.; Lee, C.J.; Acquah, S.; Kroto, $\mathrm{H}_{\text {; }}$ et al. Largescale synthesis and characterization of carbon spheres prepared by direct pyrolysis of hydrocarbons. Carbon 2005, 43, 1944-1953. [CrossRef]

50. International Centre for Diffraction Data (ICDD). Powder Diffraction File, PDF-2 Database; Announcement of New Data-Base Release; ICDD: Newtown Square, PA, USA, 2012.

51. Jakas, A.; Horvat, S. Reactivity and oxidative potential of fructose and glucose in enkephalin-sugar model systems. Amino Acids 2008, 34, 329-332. [CrossRef] [PubMed]

52. Ferrari, A.C.; Robertson, J. Interpretation of Raman spectra of disordered and amorphous carbon. Phys. Rev. 2000, 61, 14095-14107. [CrossRef]

53. Herdman, J.D.; Connelly, B.C.; Smooke, M.D.; Long, M.B.; Miller, J.H. A comparison of Raman signatures and laser-induced incandescence with direct numerical simulation of soot growth in non-premixed ethylene/air flames. Carbon 2011, 49, 5298-5311. [CrossRef]

54. Campisi, S.; Trujillo, F.J.S.; Motta, D.; Davies, T.E.; Dimitratos, N.; Villa, A. Controlling the incorporation of phosphorus functionalities on carbon nanofibers: Effects on the catalytic performance of fructose dehydration. J. Carbon Res. C 2018, 4, 9. [CrossRef]

55. Wang, G.; Zhang, M.; Liu, S.; Xie, X.; Ding, G.; Wang, Y.; Chu, P.; Gao, H.; Ren, W.; Yuan, Q.; et al. Synthesis of Layer-Tunable Graphene: A Combined Kinetic Implantation and Thermal Ejection Approach. Available online: http:/ / binarystore.wiley.com/store/10.1002/adfm.201500981/asset/supinfo/adfm201500981-sup0001-S1.pdf?v=1\&s=a288d11fec358a3ad8f9b3edd9bacfe3d0b045b5 (accessed on 14 December 2018).

56. Sevilla, M.; Fuertes, A.B.; Mokaya, R. High density hydrogen storage in super activated carbons from hydrothermally carbonized renewable organic materials. Energy Environ. Sci. 2011, 4, 1400-1410. [CrossRef]

57. Figueiredo, J.; Pereira, M.; Freitas, M.; Orfao, J. Modification of the surface chemistry of activated carbons. Carbon 1999, 37, 1379-1389. [CrossRef]

58. Mopoung, S.; Moonsri, P.; Palas, W.; Khumpai, S. Characterization and properties of activated carbon prepared from tamarind seeds by $\mathrm{KOH}$ activation for $\mathrm{Fe}(\mathrm{III})$ adsorption from aqueous solution. Sci. World J. 2015. [CrossRef] [PubMed]

59. Román, S.; Ledesma, B.; Álvarez-Murillo, A.; Al-Kassir, A.; Yusaf, T. Dependence of the microporosity of activated carbons on the lignocellulosic composition of the precursors. Energies 2017, 10, 542. [CrossRef]

60. Deng, H.; Li, G.; Yang, H.; Tang, J.; Tang, J. Preparation of activated carbons from cotton stalk by microwave assisted $\mathrm{KOH}$ and $\mathrm{K}_{2} \mathrm{CO}_{3}$ activation. Chem. Eng. J. 2010, 163, 373-381.

61. Wang, J.; Kaskel, S. KOH activation of carbon-based materials for energy storage. J. Mater. Chem. 2012, 22, 23710-23725. [CrossRef]

62. Enterría, M.; Suárez-García, F.; Martínez-Alonso, A.; Tascón, J.M.D. Synthesis of ordered micro-mesoporous carbons by activation of SBA-15 carbon replicas. Microporous Mesoporous Mater. 2012, 151, 390-396. [CrossRef] 
63. Xu, D.; Tan, X.L.; Chen, C.L.; Wang, X.K. Adsorption of Pb(II) from aqueous solution to MX-80 bentonite: Effect of $\mathrm{pH}$, ionic strength, foreign ions and temperature. Appl. Clay Sci. 2008, 41, 37-46. [CrossRef]

64. Kim, H.; Watthanaphanit, A.; Saito, N. Simple solution plasma synthesis of hierarchical nanoporous MnO for organic dye removal. Sustain. Chem. Eng. 2017, 5, 5842-5851.

65. Svilović, S.; Rušić, D.; Bašić, A. Investigations of different kinetic models of copper ions sorption on zeolite 13X. Desalination 2010, 259, 71-75. [CrossRef]

66. Bhattacharyya, K.G.; Sharma, A. Kinetics and thermodynamics of methylene blue sorption on neem (Azadirachta indica) leaf powder. Dyes Pigments 2005, 65, 51-59. [CrossRef]

67. Cheung, W.; Szeto, Y.; McKay, G. Intraparticle diffusion processes during acid dye adsorption onto chitosan. Bioresour. Technol. 2007, 98, 2897-2904. [CrossRef] [PubMed]

68. Kumar, K.V.; Kumaran, A. Removal of Methylene blue by mango seed kernel powder. Biochem. Eng. J. 2005, 27, 83-93. [CrossRef]

69. Annadurai, G.; Juang, R.-S.; Lee, D.-J. Use of cellulose-based wastes for adsorption of dyes from aqueous solutions. J. Hazard. Mater. 2002, 92, 263-274. [CrossRef]

70. Gong, R.; Li, M.; Yang, C.; Sun, Y.; Chen, J. Removal of cationic dyes from aqueous solution by adsorption on peanut hull. J. Hazard. Mater. 2005, 121, 247-250. [CrossRef] [PubMed]

71. Vadivelan, V.; Vasanth Kumar, K. Equilibrium, kinetics, mechanism, and process design for the sorption of methylene blue onto rice husk. J. Colloid Interface Sci. 2005, 286, 90-100. [CrossRef] [PubMed]

72. Ferrero, F. Dye removal by low cost adsorbents: Hazelnut shells in comparison with wood sawdust. J. Hazard. Mater. 2007, 142, 144-152. [CrossRef] [PubMed]

73. Bulut, Y.; Aydin, H. A kinetics and thermodynamics study of methylene blue adsorption on wheat shells. Desalination 2006, 194, 259-267.

(C) 2018 by the authors. Licensee MDPI, Basel, Switzerland. This article is an open access article distributed under the terms and conditions of the Creative Commons Attribution (CC BY) license (http://creativecommons.org/licenses/by/4.0/). 